\title{
Cocoa polyphenols in oxidative stress: potential health
}

\section{implications}

\author{
María Angeles Martín and Sonia Ramos*
}

Department of Metabolism and Nutrition

Institute of Food Science and Technology and Nutrition (ICTAN)

Consejo Superior de Investigaciones Científicas (CSIC)

José Antonio Novais 10

Ciudad Universitaria, 28040, Madrid

Spain

Phone: +34.91.544.56.07

Fax: +34.91.549.36.27

*Corresponding author: e-mail: s.ramos @ictan.csic.es

\begin{abstract}
Abbreviations: AKT/PKB, protein kinase B; AhR, aryl hydrocarbon receptor; AOM, azoxymethane; ARE, antioxidant response element; AP-1, activator protein-1; CAT, catalase; CVD, cardiovascular disease; COX, cyclooxygenase; CPE, cocoa phenolic extract; DEN, diethylnitrosamine; DHPAA, 3,4-dihydroxyphenylacetic acid; DMBA, 7,12-dimethylbenz(a)-anthracene; DOCA, deoxycorticosterone acetate; DSS, dextran sulphate sodium; EC, (-)-epicatechin; EpRE, electrophile response element; GCL, $\gamma$ glutamyl-cysteine-ligase; GCS, $\gamma$-glutamyl cysteine synthase; GPx, glutathione peroxidase; GR, glutathione reductase; GSH, glutathione; GSSG, oxidised glutathione; GST, glutathione-S-transferase; HFr, high-fructose-fed rats; HO-1, heme oxygenase-1; HPPA, 3-hydroxyphenylpropionic acid; HUVEC, human umbilical vein endothelial cells; iNOS, inducible nitric oxide synthase; Keap-1, Kelch-like erythroid CNC homologue-(ECH-) associated protein 1; L-NAME, N-nitro-L-arginine methyl ester; MAPK, mitogen-activated protein kinase; MDA, malondialdehyde; MPO, myeloperoxidase; NF- $\kappa \mathrm{B}$, nuclear factor kappa B; Nrf2, nuclear factor erythroid 2related factor; NQO1, NADP(H):quinone oxidoreductase-1; NO, nitric oxide; 8-OHdG, 8-oxo-7,8-dihydro-2'-deoxyguanosine; PB2, procyanidin B2; Prx, peroxiredoxins; RONS, reactive oxygen and nitrogen species; ROS, reactive oxygen species; SOD, superoxide dismutase; $t$-BOOH, tert-butylhydroperoxide; TBARS, thiobarbituric acid reactive substances; T2D, type 2 diabetes; TNF, tumour necrosis factor; TPA, 12-Otetradecanoylphorbol-13-acetate; Trx, thioredoxins; TrxR, thioredoxin reductase; TSH, total sulfhydryl groups; UDP-GT, UDP-glucuronyltransferase; UV, ultraviolet; ZDF, Zucker diabetic fatty rats.
\end{abstract}




\section{Abstract}

3 Oxidative stress has been related to the pathogenesis of chronic diseases. Therefore,

4 prevention of these pathologies by avoiding the damaging effects of free radicals and

5 oxidants has become an important potential chemopreventive and therapeutic approach.

6 In this line, epidemiologic studies have demonstrated that dietary antioxidants seem to

7 play a main role in the prevention of chronic diseases caused by oxidative stress, such

8 as cancer, cardiovascular disease and diabetes. Indeed, cocoa and its flavanols can

9 interfere in the initiation and progression of the mentioned diseases through different

10 mechanisms. This review summarizes recent progress on the health benefits of cocoa

11 and its flavanols associated to the antioxidant effects, and discusses their potential

12 molecular mechanism of action in the prevention and/or treatment of relevant chronic

13 diseases.

16 Keywords: Cocoa polyphenols, antioxidants, oxidative stress, chronic diseases, health 17 beneficial effect. 
19 Highlights

20 - Cocoa and its flavanols have a strong antioxidant activity.

$21-$ Modulation of redox status by cocoa flavanols could prevent chronic diseases.

22 - Preventive effects of cocoa against chronic diseases involve different

23 mechanisms.

24 - Preventive effects of cocoa are connected to an antioxidant-related response.

25 - Mechanistic studies and clinical trials with cocoa and its flavanols are needed.

26 


\section{Introduction}

28 Oxidative stress is recognized as a main responsible for the pathogenesis of chronic diseases such as cancer, cardiovascular diseases (CVD) and diabetes (Ramos, 2008; Valko et al., 2007). These pathologies constitute a global health problem and cause

31 death and disability to millions of people (World Health Organization, 2014).

32 Accumulating evidences suggest that a high consumption of fruits and vegetables,

33 which are rich in phenolic compounds, is inversely correlated with the risk and/or 34 incidence of cancer, CVD and diabetes (Arranz et al., 2013; Ramos, 2008; Ríos, 35 Francini \& Schinella, 2015; Shahidi \& Ambigaipalan, 2015).

36 Cocoa is a rich source of phenolic compounds and has the highest flavanol (a 37 polyphenol class) content of all foods on a per-weight basis (Vinson, Proch \& Zubik, 38 1999). Cocoa mainly contains high quantities of flavanols such as (-)-epicatechin (EC), (+)-catechin and their dimers procyanidins B2 (PB2) and B1 (Figure 1), although other polyphenols such as quercetin, isoquercitrin (quercetin 3-O-glucoside), hyperoside (quercetin 3-O-galactoside), quercetin 3-O-arabinose, apigenin, luteolin and naringenin, have also been identified at minor amounts (Table 1) (Belscak et al., 2009; Gu et al., 2006; Kim et al., 2014; Miller et al., 2009; Sánchez-Rabaneda et al., 2003). However, it should be considered that phenolic compound content can enormously vary between cocoa beans and cocoa-derived products depending on the processing conditions and the origin of the beans (Andrés-Lacueva et al., 2008; Gu et al., 2006; Kim et al., 2014; Miller et al., 2009; Vinson et al., 1999). Indeed, the alkalinization treatment that takes place during cocoa processing, results in $60 \%$ loss of the mean total flavonoid content (Andrés-Lacueva et al., 2008). (-)-Epicatechin shows a larger loss (67\%, as a mean percentage difference) than (+)-catechin (38\%), probably because of its epimerization into (-)-catechin. Similarly, a reduction is also observed for di-, tri-, 
and tetrameric procyanidins $(69 \%$ for dimer $\mathrm{B} 2,67 \%$ for trimer $\mathrm{C}$, and $31 \%$ for

53 tetramer D); for flavonols, quercetin seems to present the highest loss $(86 \%$,

54 being under the limit of quantification), whereas quercetin-3-arabinoside, and isoquercitrin showed a similar reduction (62 and 61\%, respectively) (Andrés-Lacueva et al., 2008). Moreover, it is essential to distinguish between the natural product cocoa and the processed product chocolate, which is a combination of cocoa, sugar, fat and other components (Gu et al., 2006; Miller et al., 2009).

Cocoa and cocoa-derived products are highly consumed in many countries in Europe and United States (Vinson et al., 1999) and because of its high content in polyphenols have recently attracted a great interest. Cocoa flavanols seem to act as highly effective chemopreventive agents against chronic diseases including cancer, heart disease, diabetes, neurodegenerative disease, and ageing (reviewed in Kerimi \& Williamson, 2015; Martín, Goya \& Ramos, 2013; Martín, Goya \& Ramos, 2016; Ramos, 2008). Numerous mechanisms have been proposed to account for the preventive effects of cocoa and its flavanols in cultured cells and animal models.

These mechanisms include the stimulation of tumour suppressor genes, induction of nitric oxide (NO) signalling, and activation of the insulin pathway, among many others (revised in Kerimi \& Williamson, 2015; Martín et al., 2013; Martín et al., 2016; Ramos, 2007; Ramos, 2008). The antioxidant activity of cocoa polyphenols has also been suggested as potential mechanisms for cancer, CVD and diabetes prevention (Andujar, Recio, Giner \& Rios, 2012; Martín et al., 2016; Ramos, 2008; Shahidi \& Ambigaipalan, 2015). Interestingly, the direct antioxidant effects of cocoa and its flavonoids seem to be partly based on their structural characteristics, including the hydroxylation of the basic flavan-ring system, especially 3',4'-dihydroxylation of the B-ring (catechol structure), the oligomer chain length, and the stereochemical features of the molecule (Andujar et 
al., 2012; Shahidi \& Ambigaipalan, 2015). The chemical structure of flavanols is responsible of their hydrogen donating (radical-scavenging) properties and their metalchelating antioxidant properties (Lambert \& Elias, 2010; Nakagawa et al., 2004; Shahidi \& Ambigaipalan, 2015). It is worth mentioning that due to the relatively low bioavailability of catechins and extensive metabolism it is supposed that hydrogen donation reaction could not to play a major role in vivo, but despite the levels of transition metals are tightly regulated in vivo, metal catalysis flavanol oxidation may occur (Lambert \& Elias, 2010). More importantly, cocoa and its flavanols can avert free radical-induced damage by modulating enzymes related to oxidative stress [catalase (CAT), nitric oxidase synthase (NOS), glutathione peroxidase (GPx), glutathione reductase (GR), superoxide dismutase (SOD), etc.], and by modifying the metabolism of damaging agents through the regulation of phase I drugmetabolizing enzymes (cytochrome P450) and/or phase II conjugating-enzymes (glucuronidation, sulfation, acetylation, methylation and conjugation), as well as through the regulation of redox-sensitive transcription factors [nuclear factor erythroid 2 related factor 2 (Nrf2), nuclear factor-kappaB (NF-кB), etc.].

In this regard, it should be highlighted that the biological relevance of the antioxidant effects of flavonoids (flavanols) against oxidative stress-related diseases remains to be established. Indeed, health beneficial effects of flavanoids because of the direct antioxidant action (radical-scavenging and metal-chelating properties) is likely to be limited in humans (Fraga, 2007; Hollman et al., 2011) due to their low bioavailability and extensive metabolism, which lead to low tissue and circulating concentrations in comparison to other exogenous and endogenous antioxidants (Fraga, 2007; Hollman et al., 2011; Shahidi \& Ambigaipalan, 2015). Consequently, it should also be considered that flavanol metabolites could play a role on the final health beneficial effect (Lotito \& 
102 Frei, 2006; Natsume et al., 2004; Shahidi \& Ambigaipalan, 2015) and that the

103 modulatory effect of flavonoids on enzymes related to the oxidative stress, as well as

104 phase-I and -II and transcription factors, as mentioned above and among other activities,

105 play a relevant role to prevent the oxidative damage.

106 In view of this, in the present review, the potential role for the antioxidant effects and

107 close-related molecular mechanisms of cocoa flavanols in the prevention of relevant

108 chronic diseases will be comprehensively revised, giving especial emphasis to the 109 underlying molecular mechanisms involved.

\section{2. Oxidative stress}

112 Aerobic organisms cannot avoid free radical and reactive oxygen and nitrogen

113 species (RONS) production. Free radicals and oxidants are generated during the 114 normal cellular metabolism, and also during the metabolism of toxins, of drugs

115 by cytochrome $\mathrm{P} 450$, monooxygenases, or during cell exposure to certain 116 environmental factors [ultraviolet (UV) radiation, etc.] (Finkel \& Holbrook, 117 2000). It is well established that RONS can exert beneficial or detrimental effects 118 depending on their concentrations in the cell (Shahidi \& Ambigaipalan, 2015). In 119 general terms, at low levels RONS can act as second messengers in signal 120 transduction pathways related to energy production, cell growth, etc., and are

121 required to maintain homeostatic signalling events (Finkel \& Holbrook, 2000;

122 Valko et al., 2007). However, when the level of RONS exceeds the antioxidant 123 capacity of the cell, the intracellular redox homeostasis is altered and oxidative 124 stress ensues, which may result in irreversible damage to DNA, protein and 125 lipids. Indeed, growing evidence indicates that oxidative stress is pivotal in the 126 development of non-communicable chronic diseases, such as cancer, CVD and 
127 diabetes (Ramos, 2008; Shahidi \& Ambigaipalan, 2015; Valko et al., 2007). To

128 cope with an excess of free radicals produced upon oxidative stress, humans have 129 developed sophisticated mechanisms in order to maintain the redox balance.

130 These protective mechanisms scavenge or detoxify free radicals and oxidants by

131 blocking their production, sequestering transition metals, and/or modulating the

132 antioxidant defense system that consists of non-enzymatic and enzymatic

133 antioxidant-detoxifying defenses, such as GPx, GR, glutathione-S-transferase

134 (GST), SOD, CAT, NOS, lipooxygenase, myeloperoxidase (MPO), xanthine

135 oxidase, etc. (Masella et al., 2005; Valko et al., 2007) (Figure 2).

136 Glutathione $(\mathrm{GSH})$ is considered the major non-enzymatic regulator of redox

137 balance. GSH homeostasis is regulated by its novo synthesis and other factors

138 such as utilisation, recycling and cellular export (Masella et al., 2005; Valko et 139 al., 2007). This redox cycle incorporates important antioxidant enzymes. Thus,

140 GSH can directly react with free radicals and RONS and more importantly act as

141 a substrate for GPx and GST for the detoxification of hydrogen peroxide, lipid

142 hydroperoxides and electrophilic compounds. Both GPx and GST activity can

143 eventually lower GSH cellular content and/or increase the intracellular

144 GSH/oxidised glutathione (GSSG) ratio, which could be prevented by the novo

145 GSH synthesis or by exporting GSSG to the extracellular medium (Espinosa-Diez

146 et al., 2015). GSH is recycled by the action of GR using flavin adenine

147 dinucleotide and nicotinamide adenine dinucleotide phosphate (NADPH), which

148 is crucial in the metabolism of GSH-dependent defence reactions (Masella et al., 149 2005; Valko et al., 2007).

150 Among the antioxidant enzymes, SODs catalyse the dismutation of the 151 superoxide radical into oxygen and hydrogen peroxide, and CAT coverts 
152 hydrogen peroxide to oxygen and water. Peroxiredoxins (Prx) are thiol-specific

153 proteins that use GSH to remove hydrogen peroxide and other hydroperoxides.

154 Moreover, oxidised cysteine Prx are specifically reduced by thioredoxins (Trx),

155 which can be oxidised by oxidative stress. Then, oxidised Trx, as other oxidised

156 proteins, can be reduced by thioredoxin reductase (TrxR) by using NADPH

157 (Valko et al., 2007).

158 In addition, NADPH oxidases of the NOX family share the capacity to transport 159 electrons across the plasma membrane and generate superoxide and other 160 downstream ROS; in fact, NOX proteins are considered the major source of 161 superoxide anion. All NOX family members are transmembrane proteins, and 162 NOX2, the so-called prototype NOX, consists of a membrane-bound catalytic 163 core called flavocytochrome b558, consisting of gp91phox ( $\beta$ subunit), $\mathrm{p} 22 \mathrm{phox}$ 164 ( $\alpha$ subunit) and several cytosolic regulatory subunits called p40phox, p47phox, 165 p67phox and rac1 (Bedard \& Krause, 2007; Wientjes \& Segal, 1995).

166 Transcriptional regulation of antioxidant-detoxifying genes is predominantly 167 mediated by the redox-sensitive transcription factor Nrf2, which upon its 168 activation upregulates a set of enzymes including $\mathrm{NADP}(\mathrm{H})$ :quinone 169 oxidoreductase-1 (NQO1), SOD, GST, hemeoxygenase-1 (HO-1), $\gamma$-glutamyl170 cysteine-ligase (GCL), etc. (Eggler, Gay \& Mesecar, 2008; Masella et al., 2005). 171 Nrf2 activation occurs through its liberation from the Kelch-like erythroid CNC 172 homologue-(ECH-) associated protein 1 (Keap1), which allows the nuclear factor 173 translocation and its binding to the specific consensus cis-element called 174 antioxidative responsive element (ARE) or electrophile response element 175 (EpRE). This ARE/EpRE is present in the promoter region of genes encoding 176 many antioxidant enzymes, as well as to other trans-acting factors such as small 
177 Maf-F/G/K and coactivators of ARE including cAMP response element binding

178 protein (CREB-binding protein or CBP) and p300. Additionally, Nrf2 can be

179 activated through its phosphorylation by protein kinases, such as mitogen-

180 activated protein kinase (MAPK), protein kinase C and phosphatidylinositol-3-

181 kinase (Eggler et al., 2008; Masella et al., 2005).

182 Persistently elevated oxidative stress also activate other redox-sensitive

183 transcription factors such as NF-KB and activator protein-1 (AP-1). This aberrant

184 stimulation results in the transcriptional activation of genes involved in

185 inflammation, cellular proliferation and growth, and has been related to the

186 pathophysiology of different diseases, such as cancer (Ramos, 2008; Valko et al.,

187 2007). NF-KB is a direct target for oxidation, which can affect its ability to bind

188 to DNA. Similarly, AP-1, which is often composed of dimeric combinations from

189 Jun and Fos protein families, is activated by cytokines and oxidative stimuli and

190 mostly via MAPK signalling pathway (Valko et al., 2007).

191 Oxidative stress has been involved in the early stages of the development of

192 chronic diseases, as mentioned above. Indeed, oxidative stress is present in all

193 stages of the pathology development and contributes to the progression of the

194 disease. Therefore, the prevention of the redox imbalance constitutes a very

195 efficient approach to avert chronic diseases, and in this line, phenolic compounds,

196 including cocoa flavanols, have gained interest because of their antioxidant

197 effects and regulation of cell signalling related to the redox status, namely free

198 radical scavenging, modulation of cellular antioxidant defences and close-related

199 signals (Nrf2, NF-kB, MAPK, etc.), which are the main focus of this review.

201 3. Effects of cocoa flavanols in cancer 
202 Carcinogenesis is a multistep complex process that has conventionally been

203 defined by three different stages: initiation, promotion and progression (Ramos, 204 2008). During the initiation phase cells are exposed to the carcinogen and there is 205 an interaction between the carcinogenic agent and the cell, especially with DNA. 206 At the promotion phase, which is relatively lengthy when compared to the rapid 207 previous stage, abnormal cells persist and replicate, and focus of preneoplastic 208 cells may appear. Next, in the progression stage, there is an uncontrolled cell 209 growth, new blood vessel formation occurs, and a gradual conversion of

210 premalignant to neoplastic cells, which have an augmented invasiveness and 211 metastasis potential (Ramos, 2008). Excessive oxidative stress is present during 212 all stages of cancer development, and affects a large array of signalling pathways, 213 but it has importantly been involved in the DNA damage (mutations), which is 214 crucial for the initiation of the carcinogenic process (Ramos, 2008). Besides this

215 effect, cocoa and its flavanols may exert an anti-carcinogenic effect through the 216 modulation of different molecular signals related to the cell cycle, apoptotic and 217 survival/proliferative routes, angiogenesis and metastasis processes, etc., but this 218 is out of the scope of this review and have previously been extensively revised 219 (Martín et al., 2013; Ramos, 2007; Ramos, 2008).

220 Different epidemiological and interventional human studies have reported and 221 inverse correlation between cocoa intake and cancer incidence. In the Iowa 222 Women's Study it was established an inverse epidemiological relation between 223 catechin consumption mainly from tea $(8.7-75.1 \mathrm{mg} /$ day $)$ and the incidence of 224 rectal cancer in post-menopausal women (Arts et al., 2002). Similarly, the 225 examination of death certificates (2000-2004) reported a lower rate of cancer 226 deaths in the Kuna tribe (Panama) when compared to the populations in the 
mainland; this fact has been connected to the intake of a flavanol-rich cocoa as

228 main beverage, which contributes more than $900 \mathrm{mg}$ flavanol/day (Bayard,

229 Chamorro, Motta \& Hollenberg, 2007). In this line, few human intervention trials

230 indicated that cocoa (22-31 g containing 577-651 $\mathrm{mg}$ flavanols) and cocoa

231 products such as dark chocolate (27-105 g chocolate containing 186-551 mg

232 flavanols) or cocoa drinks (100 mL drink with $187 \mathrm{mg}$ flavanols) favourably

233 affects intermediary factors in cancer progression by improving biomarkers

234 related to oxidative stress (revised in Maskarinec, 2009). However, other

235 epidemiological studies did not show any relation between cocoa, chocolate or

236 flavanol intake and prevalence of colon cancer (McKelvey, Greenland \& Sandler,

237 2000; Rouillier et al., 2005) or breast cancer (9-45.2 mg flavanols/day) (Peterson

238 et al., 2003). Likewise, in the Zutphen study catechin intake (up to $355.4 \mathrm{mg}$

239 catechin/day) derived from tea, fruits and vegetables (chocolate contributes 3\% of

240 the total catechin consumption) was not associated with epithelial cancer or lung

241 cancer (Arts et al., 2001). In addition, it is worth mentioning that a number of

242 human studies have shown a negative effect of cocoa intake on cancer incidence.

243 Indeed, a case-control study established chocolate as a risk factor for colorectal 244 cancer (Boutron-Ruault et al., 1999), and this was related to the high intake of

245 sugar and its harmful effects on insulin and IGF-I (Rouillier et al., 2005).

246 Furthermore, a relation between cocoa consumption data with worldwide

247 incidence rates of testicular cancer and hypospadias in the offspring has been

248 reported (Giannandrea, 2009), although these effects have been associated to the

249 reproductive toxicity of cocoa theobromine.

250 As mentioned above, free radicals can damage DNA and interfere with DNA

251 repair, leading to mutations that favour uncontrolled cell growth and replication, 
252 the initial steps of carcinogenesis. Thus, the antioxidant activity of cocoa

253 flavanols is of particular interest. Indeed, cocoa and its flavanols modulate the

254 first steps of carcinogenesis by protecting against cell damage through different

255 vias: a) direct free radical scavenging (hydrogen-donor) and metal-chelating, b)

256 alteration of the procarcinogenic metabolism by inhibiting phase-I drug-

257 metabolizing enzymes (cytochrome P450, CYP) and/or activating phase II

258 conjugating-enzymes, and c) induction of pro-oxidation.

259

260 3.1. Direct free radical scavenging and metal-chelating effects

261 Cocoa has a potent antioxidant capacity as compared with other products, due to

262 its high flavonoid content (Lee, Kim, Lee \& Lee, 2003). In healthy subjects

263 assigned to a daily intake of $45 \mathrm{~g}$ of dark chocolate $(860 \mathrm{mg}$ polyphenols of

264 which $58 \mathrm{mg}$ EC) or white chocolate (5 mg polyphenols, no-detected EC) for 14

265 days, it was observed that oxidative damage to the DNA of mononuclear blood

266 cells was reduced in the dark chocolate group $2 \mathrm{~h}$ after consumption, although

267 this protective effect disappeared after $22 \mathrm{~h}$ of ingestion (Spadafranca, Martinez

268 Conesa, Sirini \& Testolin, 2010). Correspondingly, in cultured human hepatic

269 HepG2 cells EC (10-20 $\mu \mathrm{M})$ protected cells from oxidative insults by preventing

270 hydroxyl radical formation and lipid peroxidation in the presence of copper

271 (Azam, Hadi, Khan \& Hadi, 2004), and EC also played a role in modulating

272 oxidative stress in lead-exposed cells (Chen, Yang, Jiao \& Zhao, 2002).

273 However, Azam and colleagues (Azam et al., 2004) have also reported that

274 copper-mediated oxidation of EC generated a more potent pro-oxidant DNA

275 cleaving agent that is active even in the absence of copper ions, pointing to the 
276 potential pro-oxidant effect of EC and its possible beneficial effects as anti-

277 carcinogenic agent (see below).

278 A protective effect of EC $(10 \mu \mathrm{M})$ has been stated after submitting DNA to $\gamma$ 279 radiation, i.e. an amelioration of DNA single-strand breaks and residual damage 280 to DNA bases (Anderson et al., 2001). Similarly, procyanidins isolated from 281 cocoa, as well as EC and (+)-catechin, inhibited 8-oxo-7,8-dihydro-2'282 deoxyguanosine $(8-\mathrm{OHdG})$ production in a concentration- and time-dependent 283 manner when calf thymus DNA was exposed to UVC radiation (Ottaviani et al., 284 2002). Thus, EC was more efficient than catechin in preventing 8-oxodG 285 formation, although monomer, tetramer, and hexamer fractions were equally 286 effective when assayed at $10 \mu \mathrm{M}$ monomer equivalent concentration. This fact 287 pointed to the relevance of epimerism and oligomerisation degree for the 288 antioxidant activity of flavan-3-ols and procyanidins (Ottaviani et al., 2002). 289 Moreover, EC $(30 \mu \mathrm{M})$ and one of its major metabolites in vivo, 3'-O-methyl 290 epicatechin, protected human fibroblasts against UVA light, although it seemed 291 that their hydrogen donating activity was not the primary mechanism of 292 protection (Basu-Modak et al., 2003). EC and (+)-catechin (10-50 $\mu \mathrm{M})$ also 293 protected HepG2 cells against oxidative DNA damage induced by N294 nitrosamines and heterocyclic amines, as reduced DNA strand breaks, the 295 formation of endonuclease III and oxidised purines and pyrimidines (Delgado, 296 Haza, García \& Morales, 2009; Haza \& Morales, 2011). On the contrary, pre297 incubation of lymphocytes from three healthy subjects with $200 \mathrm{mM}$ catechin or 298 EC did not protect against $\mathrm{H}_{2} \mathrm{O}_{2}$-induced challenge (Szeto \& Benzie, 2002). 
301 Cocoa and its phenolic compounds might exert protective effect towards

302 oxidative stress-induced damage through the modulation of phase I and II 303 enzyme activities, which also comprises the modification in the metabolic

304 transformations of the potential carcinogenic agent (Table 2). In this regard, a 305 polyphenolic cocoa extract prepared from Malaysian Natural Forastero cocoa 306 powder $(250 \mathrm{ng} / \mu \mathrm{L}$, containing $11.9 \mathrm{mg} / \mathrm{mL}$ total flavanols $)$ increased CYP1A1 307 mRNA and protein levels, as well as enzymatic activity in human MCF-7 and 308 SKBR3 breast cancer cells (Oleaga et al., 2012). Indeed, the CYP1A1 309 transcriptional activation by the polyphenolic cocoa extract was mediated through 310 aryl hydrocarbon receptor (AhR) binding to xenobiotic response elements within 311 the CYP1A1 promoter in MCF-7 cells. Additionally, CYP1A1 overexpression 312 might interfere with estrogen metabolism and the production of estrogen 313 metabolites in breast cells, which suggest that the interaction between estrogen 314 receptor $\alpha$ and AhR upon incubation with the polyphenolic cocoa extract could 315 lead to CYP1A1 induction in breast cancer cells and could alter the estrogen 316 metabolism toward the production of a relatively non-genotoxic metabolite 317 (Oleaga et al., 2012). On the contrary, an inhibitory effect on CYP1A activity 318 induced by cocoa products has been reported, and it has been related to a reduced 319 metabolic activation of carcinogens to prevent DNA damage. Accordingly, a 320 crude cacao extract $(1.325-13.25 \mathrm{mg} / \mathrm{mL}$, containing 38.89 polyphenols/g of 321 cacao powder) inhibited the CYP1A activity in liver microsomes of rats (Ohno, 322 Sakamoto, Ishizuka \& Fujita, 2009). EC (25-100 $\mu \mathrm{M})$ also repressed CYP1A 323 activity in MCF7 cells, as well as increased NADPH cytochrome c reductase 324 activity (Rodgers \& Grant, 1998). In addition, (+)-catechin (10-50 $\mu \mathrm{M})$ 325 moderately suppressed CYP1A1 activity induced by heterocyclic amines (Haza 
326 \& Morales, 2011), whereas EC (10-50 $\mu \mathrm{M})$ showed a weaker effect on the

327 inhibition of the activity of CYP1A1 in HepG2 cells (Haza \& Morales, 2011;

328 Williams et al., 2000).

329 Cocoa and its flavanols can also regulate the cellular antioxidant defences 330 through different molecular mechanisms of action (Table 2). A cocoa 331 polyphenolic extract (CPE) prepared from Natural Forastero cocoa powder (5 $332 \mu \mathrm{g} / \mathrm{mL}$, containing $755 \mathrm{mg}$ total flavanols/100 g cocoa powder) augmented the 333 activity of GPx and GR via extracellular regulated kinase activation in human 334 hepatic HepG2 cells (Martín et al., 2010a). In this line, EC (25-100 $\mu$ M) reduced 335 ROS generation and promoted cell proliferation in HepG2 cells (Granado336 Serrano et al., 2007). Indeed, these effects have been associated with EC-induced 337 Nrf2 translocation and phosphorylation via ROS formation, stimulation of Nrf2, 338 NF-kB, AP-1 and AKT (protein kinase B), as well as modulation of 339 proliferation/survival pathways (Granado-Serrano et al., 2010). In HepG2 cells 340 (+)-catechin enhanced more than EC the activity of detoxifying UDP341 glucuronyltransferase (UDP-GT) (25-50 $\mu \mathrm{M})$ (Haza \& Morales, 2011), and a 342 catechin enriched-diet ( $2 \mathrm{~g} / \mathrm{kg}$ diet, 3 weeks) decreased NQO1 activity in the rat 343 liver without modifying the hepatic activity of CAT, GPx, GST and SOD, as well 344 as lipid peroxidation and GSH levels (Wiegand et al., 2009). All these effects 345 could contribute to a potential anti-carcinogenic effect of cocoa and its flavanols. 346 Correspondingly, pre-treatment of HepG2 cells with CPE from Natural Forastero 347 cocoa powder $(0.5-50 \mu \mathrm{g} / \mathrm{mL}$, containing $755 \mathrm{mg}$ total flavanols $/ 100 \mathrm{~g}$ cocoa 348 powder) avoided the depletion of GSH and ROS overproduction caused by the 349 pro-oxidant tert-butylhydroperoxyde ( $t$-BOOH) (Martín et al., 2008). CPE also 350 averted the enhancement evoked by $t$-BOOH in malondialdehyde (MDA) levels, 
and in GPx and GR activities, and EC $(10 \mu \mathrm{M})$ prevented cell death induced by $t$ -

$352 \mathrm{BOOH}$ in the same hepatic cell line (Granado-Serrano et al., 2009a).

353 Additionally, EC pre-treatment $(25-100 \mu \mathrm{M})$ suppressed the activation of GPx and GR activities evoked by $t$-BOOH, as well as the decrease in GSH content, and restrained $t$-BOOH-induced lipid peroxidation and ROS generation (Martín et al., 2010b; Murakami et al., 2002). Similarly, catechin administration (40 $\mathrm{mg} / \mathrm{kg}$ body weight) for 10 days to mice treated with tamoxifen, a common drug used to treat and prevent breast cancer that causes mitochondrial toxicity, reduced protein- and lipid-oxidation and superoxide production in hepatic mitochondria

360 (Tabassum et al., 2007). Likewise, catechin administration increased microsomal

361 CYP content, and activities of GPx, GR, GST, SOD and CAT, and avoided GSH

362 depletion and oxidation in the liver and kidney of rats (Parvez et al., 2006;

363 Tabassum et al., 2007).

364 Importantly, rats fed with a cocoa-supplemented diet (16\% Natural Forastero cocoa powder, containing $755 \mathrm{mg}$ total flavanols/100 g cocoa powder) for 6 366 weeks and injected with a hepatotoxic agent to induce liver cancer such as

367 diethylnitrosamine (DEN), showed a potential attenuation of the post-necrotic 368 proliferation induced by DEN and a reduction of the number of initiated cells, 369 which was associated among other factors to the restoration or enhancement of 370 the diminished hepatic GSH content, as well as GPx, GST and CAT activities 371 (Granado-Serrano et al., 2009b). Later, Yang et al. (Yang, Zhang, Guan \& Hua, 372 2015) also reported a protective effect of PB2 against $\mathrm{CCl}_{4}$-induced hepatic 373 damage, as the administration of PB2 (100 mg/kg) for 7 days decreased MDA, cyclooxygenase (COX)-2 and iNOS levels, inhibited NF-KB translocation and 375 enhanced SOD, CAT and GPx activities in the liver of the animals (Yang et al., 
376 2015). Similarly, the administration of a cocoa extract prepared from a

377 Madagascarian cocoa cake sample $(34.5 \mathrm{mg} / \mathrm{kg}$, i.p., containing $50.4 \mathrm{mg}$ total

378 flavanols/g of dry matter of which $17.38 \mathrm{mg} / 100 \mathrm{~g}$ dry matter were EC) and EC

379 (2.51 mg/kg, i.p.) twice weekly for 2 weeks prevented the hepatotoxicity induced

380 by a pre-treatment with $\mathrm{CCl}_{4}(1 \mathrm{~mL} / \mathrm{kg}$ body weight, i.p. twice a week)

381 (Giacometti, Muhvic', Pavletic' \& Đudaric, 2016). Thus, the cocoa extract and

382 EC post-treatments retuned to control values the $\mathrm{CCl}_{4}$-enhanced SOD activity,

383 and partly restored the diminished total protein thiols levels and the $\mathrm{CCl}_{4-}$

384 increased CAT activity, showing cocoa extract a more remarkable effect than EC

385 for augmenting CAT activity (Giacometti et al., 2016). EC (15 mg/kg body

386 weight, 3 days) also showed a preventive effect against $\gamma$-irradiation-induced

387 damage (Sinha et al., 2012). EC avoided the increase of lipid peroxidation and

388 NF-kB translocation, as well as the reduction in the activities of SOD and CAT,

389 and GSH content in the liver of the irradiated mice.

390 All these studies suggest the protective effect and potential benefits of cocoa

391 flavanols in the prevention of hepatic cancer by suppressing the causative role of 392 enhanced oxidative stress.

393 Cocoa and its flavanols have also proved to play a relevant role in colon cancer.

394 Accordingly, PB2 (1-10 $\mu \mathrm{M})$ evoked a dose-dependent increase in GPx, GR and

395 GST activities in human colonic Caco-2 cells, which could be related with an

396 improved cell response to an oxidative challenge (Rodriguez-Ramiro et al.,

397 2011a). Hence, pre-treatment of Caco-2 cells with PB2 (1-10 $\mu \mathrm{M})$ reduced ROS

398 production and improved cell viability in comparison to $t$-BOOH-incubated cells

399 (Rodriguez-Ramiro et al., 2011a). PB2 (10 $\mu \mathrm{M})$ also showed a protective effect

400 against $t$-BOOH-induced oxidative damage by up-regulating the expression of 
401 GSTP1 via a mechanism that involved MAPK activation and Nrf2 translocation

402 (Rodriguez-Ramiro et al., 2012). Similarly, Caco-2 cells pre-treated with CPE 403 prepared from Natural Forastero cocoa powder $(10 \mu \mathrm{g} / \mathrm{mL}$, containing $755 \mathrm{mg}$ 404 total flavanols/100 g cocoa powder $), \mathrm{PB} 2(10 \mu \mathrm{M})$ and $\mathrm{EC}(10 \mu \mathrm{M})$ counteracted 405 acrylamide-induced cytotoxicity by preventing GSH depletion and ROS 406 generation (Rodriguez-Ramiro et al., 2011b). Indeed, CPE and PB2 avoided the 407 acrylamide-induced damage by increasing $\gamma$-glutamyl cysteine synthase (GCS) 408 and GST levels. Catechin $(100 \mu \mathrm{M})$ also prevented the oxidative injury induced 409 with ketoprofen, a widely used anti-inflammatory drug, as decreased lipid 410 peroxidation, DNA oxidative damage and ROS generation, and increased total 411 sulfhydryl groups (TSH), as well as GPx and GR activities, and the expression of 412 Nrf2 and HO-1 in intestinal Int-407 cells (Cheng, Wu, Ho \& Yen, 2013). 413 Moreover, catechin administration (14 or $35 \mathrm{mg} / \mathrm{kg} /$ day) in rats during 21 days 414 prevented lipid and DNA oxidative damage, and the diminution of GSH/GSSG 415 ratio, GSH content and GPx and GR activities in intestinal mucosa (Cheng et al., 416 2013).

417 Procyanidin dimers and trimers isolated from cocoa also protect against oxidants 418 and other molecules that threaten the integrity of the bilayer by interacting with 419 membrane phospholipids (Verstraeten et al., 2005). Hence, a hexameric 420 procyanidin $(2.5-20 \mu \mathrm{M})$ fraction isolated from Brazilian cocoa beans interacted 421 with Caco-2 cell membranes, and it inhibited the deoxycholic-induced 422 cytotoxicity, oxidant generation, NADPH oxidase and AP-1 activations, as well 423 as deoxycholic-triggered increase in cellular calcium (Da Silva et al., 2012; 424 Erlejman, Fraga \& Oteiza, 2006). In addition, it has been reported that cocoa 425 flavanols and procyanidins alter the cellular oxidant production by inhibiting the 
426 binding of a ligand to its receptor. This is the case for tumour necrosis factor

427 (TNF)- $\alpha$, whose binding to its receptor activates NADPH oxidase and 428 subsequently increases superoxide anion production (Yang \& Rizzo, 2007).

429 Consequently, in Caco-2 cells, hexameric procyanidins $(2.5-20 \mu \mathrm{M})$ and EC (0.5-

$4305 \mu \mathrm{M}$ ) inhibited the TNF $\alpha$-triggered signalling, i.e ROS production, NAPDH 431 oxidase, iNOS and NF-kB pathway (Contreras, Ricciardi, Cremonini \& Oteiza, 432 2015; Erlejman, Jaggers, Fraga \& Oteiza, 2008).

433 Interestingly, the administration of a cocoa-rich diet (12\% Natural Forastero 434 cocoa powder, containing $755 \mathrm{mg}$ total flavanols/100 g powder, and $10 \%$ of dark 435 chocolate with $72 \%$ cocoa from Ghirardelli Chocolate Company containing 43 $436 \mathrm{mg}$ procyanidin/g chocolate) during 8 or 11 weeks prevented azoxymethane 437 (AOM)-induced colonic preneoplastic lesions in rats, as reduced oxidative stress, 438 cell proliferation and inflammation (Hong et al., 2013; Rodriguez-Ramiro et al., 439 2013; Rodriguez-Ramiro et al., 2011c). Indeed, cocoa prevented AOM-induced 440 protein and lipid oxidation, as well as the diminution in the activities of GPx, GR, 441 CAT and GST, and GSH content (Hong et al., 2013; Rodriguez-Ramiro et al., 442 2011c). In addition, both cocoa-enriched diets downregulated COX-2, iNOS and 443 NF-kB colonic levels in rats (Hong et al., 2013; Rodriguez-Ramiro et al., 2013). 444 A comparable result has also been shown in a colitis-associated cancer animal 445 model in which mice received AOM/dextran sulphate sodium (DSS) and were 446 fed with 5 or $10 \%$ cocoa-enriched diet for 62 days (Pandurangan et al., 2015). 447 Administration of Malaysian cocoa powder to AOM/DSS-treated mice decreased 448 MDA, COX-2 and iNOS levels, and increased the colonic activities of SOD, 449 CAT, GPx and GR, and GSH content. In addition, cocoa activated Nrf2, NQO1 450 and UDP-GT (Pandurangan et al., 2015). All this suggest that cocoa could 
counteract carcinogen-induced toxicity as protected against the oxidative damage, and highly averted the appearance of preneoplastic colonic lesions by reinforcing the endogenous defence of the colonic tissue.

In the brain, cocoa and its flavanols also exert beneficial effects. EC (100 nM) increased GSH content and stimulated $\mathrm{Nrf} 2$ via AKT in astrocytes from mice (Bahia, Rattray \& Williams, 2008). Similarly, catechin (0.1-10 $\mu \mathrm{M})$ reinforced the antioxidant defences in cultured rat brain astrocytes: enhanced activity and mRNA levels of SOD, and CAT and GPx mRNA values (Chan et al., 2002). In addition, a cocoa extract prepared from Malaysian Natural Forastero cocoa

460 powder $(5-30 \mu \mathrm{g} / \mathrm{mL}$, containing $20.4 \mathrm{mg} / \mathrm{mL}$ of total phenols expressed as 461 catechin) and EC (12.4-100 $\mu \mathrm{M})$ showed a neuroprotective effect in SH-SY5Y 462 cells by decreasing ROS production through MAPK modulation in $\mathrm{H}_{2} \mathrm{O}_{2} / \mathrm{Fe}^{2+}$ 463 incubated cells (Ramiro-Puig et al., 2009).

464 Cocoa flavanols have also demonstrated valuable effects against skin cancer. 465 Dietary supplementation with $2 \%$ catechin during 2 or 4 weeks protected 466 epidermal cells of mice against UVB-induced damage through the modulation of 467 antioxidant defences: increased activities of CAT and SOD, transiently enhanced 468 GPx activity and moderated thickening of epidermis (Jeon et al., 2003). Likewise, 469 an emulsified gel of catechin averted 7,12-dimethylbenz(a)-anthracene-(DMBA)470 induced and 12-O-tetradecanoylphorbol-13-acetate-(TPA)-promoted squamous 471 skin carcinoma in mice (Monga et al., 2014). Catechin gel topical administration $472(\approx 1 \mathrm{mg} / \mathrm{cm} 2$ skin area, 3 times a week for 6 weeks $)$ decreased lipid peroxidation, 473 enhanced SOD, CAT, GST, GPx and GR activities, as well as GSH content, and 474 downregulated COX-2, iNOS and NF-KB levels in comparison to DMBA/TPA475 treated animals. On the contrary, catechin $(150 \mu \mathrm{M})$ did not show any antioxidant 
effect against $\mathrm{H}_{2} \mathrm{O}_{2}$-induced oxidative stress in RL95 endometrial cells, as it did

477 not recover the diminished cell viability (Estany et al., 2007).

478

\subsection{Induction of pro-oxidation}

480 Despite the well-defined antioxidant characteristics, cocoa flavanols can become 481 pro-oxidants under certain conditions, such as high concentrations and in the 482 presence of redox-active metals (Sakano et al., 2005). Thus, PB2 (20 $\mu \mathrm{M})$ prevented the formation of 8-OHdG in human HL-60 leukaemia cells treated with an $\mathrm{H}_{2} \mathrm{O}_{2}$-generating system. In contrast, at high concentrations PB2 (200 $\left.\mu \mathrm{M}\right)$ increased the formation of $8-\mathrm{OHdG}$ in the same cell line (Sakano et al., 2005). Experiments with calf thymus DNA also revealed that PB2 (10-30 $\mu \mathrm{M})$ decreased 8-OHdG formation promoted by $\mathrm{Fe}(\mathrm{II}) / \mathrm{H}_{2} \mathrm{O}_{2}$, whereas at the same concentrations PB2 induced DNA damage in the presence of $\mathrm{Cu}(\mathrm{II})$, and $\mathrm{H}_{2} \mathrm{O}_{2}$ extensively enhanced it (Sakano et al., 2005). This suggests that PB2 exerts both antioxidant and pro-oxidant properties by interacting with $\mathrm{H}_{2} \mathrm{O}_{2}$ and metal ions. Similarly,

491 EC induced oxidative DNA damage in human acute myeloid leukaemia cultured 492 cells (Papiez, Baran, Bukowska-Strakova \& Krosniak, 2011), potentiated the 493 effect of etoposide, a drug commonly used for the treatment of this disease, in rats, and partially protected against the haemotoxicity caused by the drug (Papiez, Bukowska-Strakova, Krzysciak \& Baran, 2012). Etoposide was supplied every 496 day for 3 consecutive days starting on 21st day. Administration of EC by daily 497 gavage (40 mg/kg body weight) during 23 days after the inoculation of rats with 498 splenic-derived leukaemia cells led to enhanced plasmatic levels of MDA, 499 indicating that EC increased the etoposide-induced oxidative stress in leukaemic 500 rats (Papiez et al., 2012). This synergistic action could contribute to augment the 
anticancer activity of etoposide in leukaemic rats and it could be useful in the

502 anticancer therapy against acute myeloid leukaemia. Indeed, EC reduced catalase

503 activity, which has been associated to ROS accumulation and to its anticancer

504 activity (Pal, Dey \& Saha, 2014). This accumulation of ROS, as mentioned

505 above, is also connected to the alteration of multiple signal transduction pathways

506 leading to the induction of cell death (cell cycle, apoptosis, etc.) (Revised in

507 Martín et al., 2013; Ramos, 2007; Ramos, 2008).

508

509 All these evidences indicate that cocoa might exert a beneficial effect in cancer

510 prevention. However, the number of studies in humans is still limited to clearly

511 establish an inverse relation between cocoa flavanol consumption and cancer risk.

512 Indeed, these human studies have produced conflicting results, and some of them

513 have shown that cocoa or its flavanols actually increase cancer risks (Boutron-

514 Ruault et al., 1999). In this regard, caution is required, since it has also been

515 reported that administration of phenolic compounds might compromise the

516 efficacy of some chemotherapeutic drugs by protecting against their induced

517 toxicity due to their antioxidant properties of phenolic compounds

518 (Somasundaran et al., 2002). Additionally, it should be considered that different

519 efficacies for cocoa or its flavanols (beneficial effect or lack of effect) have been

520 described against diverse type of cancers, and also different cocoa flavanols have

521 demonstrated distinct effect against the same type of cancer. All this

522 demonstrates the difficulty to anticipate the outcome and the necessity to

523 understand the molecular mechanism of action of these natural compounds in

524 each particular context. In fact, most of the experimental features reported in vitro

525 and in vivo models have not been proved to occur in humans, and some data 
526 obtained, especially in cultured cells, might not be physiologically appropriated

527 due to the selected experimental conditions (cell type, dose, length of treatment, 528 type of substance, etc.). Future studies should detail information about the product 529 used, the exact content in polyphenols, and flavanol plasma concentrations to employ 530 realistic and physiological relevant doses in the experimental models.

\section{4. Effects of cocoa flavanols in CVD}

533 Cardiovascular disease, involving peripheral vascular disease, atherosclerosis, 534 heart failure, ischemic strokes and myocardial infarction, remains the leading 535 cause of death in developed countries (World Health Organization, 2014). The 536 aetiology of CVD is very complex but it has been described that oxidative stress 537 plays an essential role in the development of atherosclerosis and contribute to the 538 progress of cardiovascular events (Dhalla, Temsah \& Netticadan, 2000). In fact, most cardiovascular risk factors are related to an increase in free radicals and

540 oxidants in endothelial vascular cells (Huige, Horke \& Förstermann, 2013), and 541 in this line, the increased NOX activity contribute to the pathology (Bedard \&

542 Krause, 2007). In healthy individuals, the vascular endothelium regulates an 543 intricate balance of factors that maintain vascular homeostasis and normal arterial 544 function (Tousoulis et al., 2014). Among these factors, nitric oxide (NO), 545 synthetized by the endothelial NOS, is critically involved in the control of 546 vascular tone, tissue blood flow, smooth muscle cell proliferation or vessel wall 547 inflammation (Tousoulis et al., 2014). However, under an oxidative stress environment NO availability decreases and the endothelium loses its

549 physiological properties and shifts toward a vasoconstrictor, pro-thrombotic and 550 proinflammatory state leading to endothelial dysfunction and the development of 
551 atherosclerosis and CVD (Tousoulis et al., 2014). Given the implication of

552 oxidative stress in several unhealthy vascular conditions the effects of natural 553 antioxidants such as cocoa flavanols appear to be highly relevant and could play 554 an important role in the prevention of endothelial dysfunction and CVD. It is 555 interesting to note that cocoa flavanols also possess non-antioxidant mechanisms 556 that could protect the cardiovascular system, such as the improvement of NO 557 availability and the reduction of inflammation, blood pressure and platelet 558 aggregation and adhesion (Andujar et al., 2012), but here their antioxidant effect 559 is specifically going to be revised.

560 Both epidemiological and clinical studies have linked cocoa to many 561 cardiovascular benefits. Several data from large-scale studies have shown an 562 inverse relationship between dark chocolate and cocoa intake and the risk of 563 CVD (Higginbotham \& Taub, 2015). The most recent prospective 564 epidemiological study has reviewed chocolate intake and cardiovascular 565 outcomes using data from 20,951 participants of the European Prospective 566 Investigation into Cancer (EPIC)-Norfolk cohort (Kwok et al., 2015). The results 567 obtained were further compared in a meta-analysis with previous epidemiological 568 studies and showed that higher chocolate consumption (16-99 g chocolate/day) was significantly associated with lower risk of coronary artery disease, stroke, 570 and cardiovascular mortality (Kwok et al., 2015). It has been suggested that these 571 protective effects are in part due to the antioxidant properties of cocoa flavanols, 572 which seem to prevent the oxidation of LDL-cholesterol (Andujar et al., 2012). 573 Supporting this, in the last recent years, a significant number of clinical studies 574 developed in humans have described that daily cocoa or cocoa-derived product 575 intake ranging from 88 to $1052 \mathrm{mg}$ flavanols increased plasma antioxidant 
capacity, reduce LDL oxidation, as well as lipid and DNA damage (Revised in

577 Arranz et al., 2013; Kerimi \& Williamson, 2015). In these studies, different 578 biomarkers of oxidative stress in plasma including total antioxidant capacity 579 (Davison et al., 2012; Hermann et al., 2006; Rein et al., 2000a), LDL oxidation 580 (Baba et al., 2007; Khan et al., 2012) and levels of MDA (Fraga et al., 2005; 581 Sarriá et al., 2012), thiobarbituric acid reactive substances (TBARS) (Nanetti et 582 al., 2012; Rein et al., 2000b) or F2- or 8-isoprostanes (Carnevale et al., 2012; 583 Stote et al., 2012; Wiswedel et al., 2004) have been analysed in both healthy and 584 at-risk groups. Although, in general, favourable changes in serum oxidative 585 measurements have been observed after dark chocolate or cocoa consumption 586 (366-563 $\mathrm{mg}$ total catechins/100 g), there were also few studies that reported no 587 significant differences in oxidative biomarkers (Engler et al., 2004; Mursu et al., 588 2004).

589 Regarding the potential antioxidant mechanisms of cocoa flavanols to protect 590 vascular system from oxidative injury, both the induction of antioxidant and 591 detoxifying enzymes, and the inhibition of pro-oxidant enzymes have been 592 implicated (Table 3).

593

\section{4.1. Induction of antioxidant enzymes}

595 Numerous studies have demonstrated that cocoa flavanols are effective 596 scavengers of physiologically relevant free radicals and oxidants in vitro (Hatano 597 et al., 2002). However, their bioavailability in vivo would not be consistent with 598 an antioxidant effect as free radical scavenger, as mentioned above (Galleano, 599 Oteiza \& Fraga, 2009). In this line, an interesting approach to reduce oxidative 600 stress demonstrated by cocoa flavanols is the induction of endogenous 
601 antioxidant and cytoprotective enzymes via activation of the nuclear transcription

602 factor Nrf2 (Granado-Serrano et al., 2010; Pandurangan et al., 2015; Rodriguez-

603 Ramiro et al., 2012). In this line, Gómez Guzmán et al. (2011) showed that EC at

604 doses equivalent to those that can be achieved in the human diet (2 or $10 \mathrm{mg} / \mathrm{kg}$ 605 body weight) reduced oxidative stress in the vascular wall of rats receiving $\mathrm{N}$ 606 nitro-L-arginine methyl ester (hypertensive L-NAME rats). Besides, it has been 607 demonstrated that these single daily doses of EC ( 2 or $10 \mathrm{mg} / \mathrm{kg}$ body weight) 608 increased the expression of both Nrf2 and Nrf2 target genes (NQO1, GCLC and 609 HO-1) in the aorta of control and deoxycorticosterone acetate (DOCA)-salt 610 hypertensive rats (Gomez-Guzman et al., 2012). On the other hand, Ruijters et al. 611 (2013) established that EC $(0.5-10 \mu \mathrm{M})$, catechin $(0.5-10 \mu \mathrm{M})$ and their 612 metabolites $(0.5-10 \mu \mathrm{M})$ protected primary human umbilical vein endothelial 613 cells (HUVEC) against intracellular oxidative stress. However, they suggested

614 that this effect was mainly related to the direct radical scavenging properties of 615 cocoa flavanols since neither EC nor catechin changed HO-1 gene expression, an 616 important downstream target of the Nrf2 pathway.

617

618 4.2. Inhibition of pro-oxidant enzymes

619 Dietary flavonoids may also act as antioxidants in vivo by inhibition of pro620 oxidant enzymes such as NOX (Schewe, Steffen \& Sies, 2008), which is 621 considered the major source of superoxide anion in the vascular wall. Thus, NOX 622 are induced or activated by cardiovascular risk factors and importantly contribute 623 to the oxidative burden of vascular diseases (Brandes, Weissmann \& Schroder, 624 2010). The superoxide anion generated by NOX in the vascular system directly 625 reacts with NO leading to the formation of a highly oxidizing agent and 
626 restraining its availability. In this line, cocoa polyphenols and their metabolites

627 may contribute to the control of NOX activity at levels low enough not to harm 628 vascular tissues. In particular, in the concentration range around $10 \mu \mathrm{M}, \mathrm{PB} 2$ and 629 the (-)-EC phase II metabolites 3'- and 4'-monomethyl ethers have been proved 630 to act as inhibitors of NOX in intact HUVEC cells and cell lysates (Steffen, 631 Gruber, Schewe \& Sies, 2008). Chronic EC treatment (2 and $10 \mathrm{mg} / \mathrm{kg}$ body 632 weight) prevented the increased in NOX activity in aortic tissue from 633 hypertensive L-NAME-treated animals by inhibiting the p22phox gene 634 overexpression (Gómez-Guzmán et al., 2011). Similar results were observed for 635 the same group in the DOCA-salt rat model of hypertension (Gomez-Guzman et 636 al., 2012). Chronic EC (10 mg/kg of body weight) prevented the up-regulation of 637 p22phox and p47phox, as well as the increased NOX activity and the vascular 638 superoxide content in aortic tissue induced by DOCA (Gomez-Guzman et al., 639 2012). Likewise, a short term treatment (4 days) of EC administration (4 g/kg 640 diet) avoided the L-NAME-mediated increase in both superoxide anion 641 production and NOX subunit p47phox expression (Litterio et al., 2012). The 642 same group demonstrated in a model of metabolic syndrome (high-fructose-fed 643 rats) that dietary administration of EC (20 mg/kg body weight) for 8 weeks 644 prevented superoxide anion production and the expression of the NOX subunits 645 p47phox and p22phox (Litterio et al., 2015). More recently, it has been showed 646 that short-term administration of EC ( $4 \mathrm{~g} / \mathrm{kg}$ diet) also prevented changes in 647 oxidative stress and NO metabolism induced by L-NAME in the heart 648 (Piotrkowski, Calabró, Galleano \& Fraga, 2015). These effects seem to be mostly 649 associated with the modulation of NOX through changes in the expression of the 650 regulatory subunit $\mathrm{p} 47$ phox. Interestingly, the inhibition of superoxide production 
651 by EC could be of high relevance in keeping low the vascular and systemic

652 oxidative stress associated with hypertension and other risk factors of CVD.

653 Finally, a small number of studies have also analysed the effect of cocoa

654 flavanols in the expression of NOX in human intervention studies. In this line,

655 that the intake of $40 \mathrm{~g}$ of dark chocolate (cocoa $>85 \%$, containing $799 \mathrm{mg} / \mathrm{L}$ total

656 polyphenols) reduced the activation of NOX2 in smokers (Carnevale et al., 2012;

657 Loffredo et al., 2011). Likewise, the same dose of dark chocolate improved

658 walking autonomy in patients with peripheral artery disease with a mechanism

659 possibly related to a decreased oxidative stress involving NOX2 regulation

660 (Loffredo et al., 2014).

661 Another mechanism to reduce oxidative stress by cocoa flavanols is the inhibition

662 of the proinflammatory proatherogenic enzyme MPO. MPO seems to mediate 663 oxidative modifications of LDL (oxLDL), which appear to be crucial for 664 atherogenesis (Steinberg, 1997). Nitrite, the major oxidation product of NO, is 665 the substrate of MPO and favours the production of nitrogen reactive species, 666 which contributes to oxidise LDL (Schewe \& Sies, 2005). Micromolar 667 concentrations of EC $(2 \mu \mathrm{M})$ were found to suppress LDL oxidation induced by 668 MPO in the presence of physiologically relevant concentrations of nitrite (Sies, 669 Schewe, Heiss \& Kelm, 2005). These results are in line with those recently 670 obtained in an in vivo study where the consumption of $1.4 \mathrm{~g}$ of cocoa extract 671 (645.3 mg of polyphenols) as part of ready-to-eat meals and within a hypocaloric 672 diet during 4 weeks decreased the MPO levels and improved the oxidative status 673 (oxLDL) in middle-aged subjects (Ibero-Baraibar et al., 2014).

674 
675 In view of all these results, data from experimental models and human clinical

676 studies have demonstrated an inverse relation between cocoa and the risk of

677 CVD. In fact, European Food Safety Authority (EFSA) has validated the health

678 claim that established a relation between the consumption of cocoa flavanols and

679 a cardioprotective effect (European Food Safety Authority, 2012). However,

680 more human trials also at long-term are needed to determine the impact of cocoa

681 consumption on cardiovascular effects, as well as to clarify the mechanisms

682 involved on their actions. Special emphasis should be given to the product

683 selected and its polyphenolic content.

684

685 5. Effects of cocoa flavanols in diabetes

686 Diabetes mellitus is a complex metabolic disorder characterised by persistent elevated 687 blood glucose (hyperglycaemia). Type 2 diabetes (T2D) is the most common form of 688 diabetes and results from a combination of genetic and acquired factors that provoke a 689 progressive insulin secretory defect in pancreatic beta cells and cellular failure to 690 respond properly to insulin, a condition known as insulin resistance (American Diabetes 691 Association, 2014). T2D is one of the most common chronic diseases and its prevalence 692 is increasing worldwide with accelerating rates in developing countries (International 693 Federation of Diabetes, 2014). Chronic hyperglycaemia in T2D is associated with long694 term dysfunction and failure of different organs (eyes, kidneys, nerves, heart, and blood 695 vessels) that generates serious health complications including CVD, kidney failure, 696 neuropathy, blindness and amputations (Folli et al., 2011). Consequently, the health697 related quality of life and overall life expectancy of T2D patients decrease being 698 diabetic complications (both micro- and macro-vascular) one of the leading causes of 699 death worldwide (World Health Organization, 2014). 
700 A growing body of evidence suggests that oxidative stress plays a key role not only in

701 diabetes development but also in the pathogenesis of micro- and macro-vascular

702 diabetic complications (Folli et al., 2011). Hyperglycaemia, insulin resistance,

703 hyperinsulinaemia, and dyslipidaemia in diabetic milieu contribute to the oxidative

704 stress via different mechanisms (Folli et al., 2011; Giacco \& Brownlee, 2010). As such,

705 therapeutic strategies to reduce free radicals and oxidants or enhance their neutralisation

706 should have protective effects against diabetes and diabetic complications. According to

707 this, in the last past years, there was a growing interest in the identification of natural

708 antioxidant compounds that can act as anti-diabetic agents for its potential ability to

709 alleviate oxidative stress with low toxicity and very few adverse side effects (Martín et

710 al., 2016; Ríos et al., 2015).

711 In this line, epidemiological investigations revealed an inverse correlation between the

712 dietary intake of flavanols, including cocoa flavanols, and the incidence of diabetes

713 (Bayard et al., 2007; Greenberg, 2015; Kim, Keogh \& Clifton, 2016). Likewise, there

714 are evidence based on interventional studies that flavanol-rich dark chocolate containing

$715500 \mathrm{mg}$ or $1008 \mathrm{mg}$ of total phenols/day can improve glucose homeostasis and enhance

716 both insulin secretion and sensitivity in non-diabetic patients (Grassi, Desideri \& Ferri,

717 2013). However, very few clinical trials are available providing solid evidence for

718 health benefits of cocoa in diabetic patients (reviewed in Martín et al., 2016). In

719 addition, most of these studies evaluated clinical markers associated with diabetes such

720 as blood pressure, lipid profile, endothelial function or insulin resistance and

721 exclusively two of them have reported the effects of cocoa on markers related to

722 oxidative stress. Accordingly, a high-polyphenol chocolate providing $16.6 \mathrm{mg}$ of

723 epicatechins protected against acute hyperglycaemia-induced oxidative stress (evaluated

724 as 15-F2-isoprostane) in individuals with T2D (Mellor et al., 2013). More recently, 
725 Parsaeyan and colleagues (2014) have also assessed the effect of a cocoa power on the

726 lipid profile and peroxidation in T2D patients. One hundred people with T2D were 727 included in a randomized clinical control trial. Fifty T2D-treated subjects received 10

728 grams of cocoa powder and 10 grams of milk powder dissolved in $250 \mathrm{~mL}$ of boiling

729 water, and the other fifty T2D control subjects received only 10 grams of milk powder

730 dissolved in $250 \mathrm{~mL}$ of boiling water, twice daily for 6 weeks. The results showed that

731 cocoa consumption reduced lipid peroxidation (evaluated as MDA levels) in T2D-

732 medicated patients.

733 Concerning the mechanism, different in vitro and animal studies have indicated that,

734 independent of their functions as antioxidant, cocoa and its main phenolic compounds

735 can act as direct anti-diabetic agents by improving glucose tolerance and insulin

736 sensitivity, among other actions in the pancreas, liver, adipose tissue and skeletal

737 muscle (Martín et al., 2016). Nevertheless, in the present review we will primarily focus

738 on the preventive effects of cocoa and its main flavanols against the oxidative damage

739 associated to T2D. In particular, cocoa flavanols and its metabolites have demonstrated

740 their ability to modulate the oxidative stress in central tissues and organs involved in

741 diabetes (Table 4). This effect contributes to improve the insulin response and the 742 glycaemic control, and therefore, to prevent the development of T2D and its 743 complications associated.

745 5.1. Modulation of oxidative stress in pancreas

746 Oxidative stress has been widely implicated in the worsening of diabetes by affecting 747 the secretion and viability of beta cells (Bensellam, Laybutt \& Jonas, 2012). Pancreatic 748 beta cells have been reported to exhibit particular sensitivity to oxidative stress-induced 749 injury due to the low expression level of antioxidant enzymes (Robertson, 2010). 
750 Therefore, induction of these protective/antioxidant enzymes seems to be an important

751 strategy to improve beta cell survival in diabetes. In this line, it has been demonstrated

752 that the treatment of INS-1E pancreatic beta cells during 20 hours with a cocoa phenolic

753 extract (CPE) prepared from Natural Forastero cocoa powder $(5-20 \mu \mathrm{g} / \mathrm{mL}$, containing

$754755 \mathrm{mg}$ total flavanols/100 g cocoa powder) prevented the oxidative stress induced by

755 the potent pro-oxidant $t$-BOOH (Martin et al., 2013). In particular, CPE-pretreated cells

756 presented a substantial increase in GPx and GR activities and reduced levels of carbonyl

757 groups (protein oxidation) after the submission of cells to the pro-oxidant $t$-BOOH

758 (Martin et al., 2013). Similar results have been obtained with EC in the same

759 experimental conditions. Thus, pre-treatment of INS-1E cells with EC (5-20 $\mu \mathrm{M}$ for 20

$760 \mathrm{~h}$ ) avoided $t$-BOOH-induced ROS generation, GSH decrease and protein oxidative

761 injury (evaluated as carbonyl groups increase) (Martin et al., 2014). Besides, catechin

762 incubation $\left(50 \mu \mathrm{M}\right.$ for $24 \mathrm{~h}$ ) was able to decrease $\mathrm{H}_{2} \mathrm{O}_{2}$-induced oxidative stress and

763 lipid peroxidation, measured by TBARS assay in HIT pancreatic beta cells (Lapidot,

764 Walker \& Kanner, 2002). Interestingly, the antioxidant effect of different metabolites of

765 cocoa produced by colonic microbiota, 3,4-dihydroxyphenylacetic acid (DHPAA) and

766 3-hydroxyphenylpropionic acid (HPPA) has also been investigated in INS-1E cells. Pre-

767 treatment of INS-1E beta cells with DHPAA $(5 \mu \mathrm{M}$ for $20 \mathrm{~h})$ and HPPA $(1 \mu \mathrm{M}$ for $20 \mathrm{~h})$

768 prevented the oxidative stress by reducing ROS generation, carbonyl groups and cell

769 death caused by $t$-BOOH (Fernández-Millán et al., 2014).

770 Finally, only one study has showed the ability of cocoa to strengthen antioxidant

771 defences and to protect pancreatic beta cells against oxidative stress in vivo. In this

772 work, the ingestion of a cocoa-rich diet (10\% Natural Forastero cocoa powder,

773 containing $755 \mathrm{mg}$ total flavanols/100 g cocoa powder) for 9 weeks was able to

774 preserve pancreatic beta cell mass and function in an animal model of T2D, the Zucker 
775 diabetic fatty (ZDF) rat (Fernández-Millán et al., 2015). In this model, oxidative stress

776 induced by the diabetic condition increased markers of protein and lipid oxidation

777 (carbonyl groups and TBARS, respectively) in pancreas and led to beta cell apoptosis.

778 However, cocoa diet increased the activity of antioxidant defences, mainly GPx and

779 GR, and reduced the pancreatic oxidative stress preventing beta cell apoptosis.

780 Consequently, the cocoa-rich diet was able to delay the loss of functional beta-cell mass

781 and the progression of diabetes in a T2D animal model.

782

\section{5.2. Modulation of oxidative stress in insulin-target tissues}

784 Under a diabetic condition it has been showed that oxidative stress is induced in insulin-

785 target tissues such as liver, fat, and muscle, leading to a situation of oxidative stress,

786 which has been involved in the development of insulin resistance and causes cellular

787 damage (Folli et al., 2011). Therefore, ameliorating oxidative stress with cocoa

788 antioxidants seems to be an effective strategy for reducing the development and

789 progression of T2D.

790 Different in vitro and in vivo studies have demonstrated that cocoa and its flavanols can

791 exert beneficial effects in a hyperglycaemic environment in the liver. In this regard, a

792 cocoa polyphenolic extract (CPE) prepared from Natural Forastero cocoa powder (1

$793 \mu \mathrm{g} / \mathrm{mL}$, containing $755 \mathrm{mg}$ total flavanols $/ 100 \mathrm{~g}$ cocoa powder) and its main flavanol

794 EC $(10 \mu \mathrm{M})$ protected HepG2 cells against a high-glucose-induced oxidative insult

795 (Cordero-Herrera, Martin, Goya \& Ramos, 2015a). Thus, the increase in ROS

796 generation and oxidative protein damage (carbonyl content), as well as the decrease in

797 GSH concentration induced by high-glucose were significantly prevented in hepatic

798 HepG2 cells pre-treated during 24 hours with EC or CPE. Moreover, EC and CPE 799 modulated high-glucose-induced upregulation of Nrf2, and GPx and GR activities. In 
800 the same way, a cocoa-supplemented diet (10\% Natural Forastero cocoa powder, 801 containing $755 \mathrm{mg}$ total flavanols/100 g cocoa powder) administered during 9 weeks to 802 diabetic ZDF rats averted the hepatic dysfunction by preventing the increase in ROS 803 generation and the oxidative protein damage (carbonyl groups) induced in these animals 804 for the diabetic milieu. In addition, the cocoa rich-diet recuperated the hepatic SOD 805 activity, enhanced the hepatic HO-1 activity and recovered the Nrf2 levels to control 806 values (Cordero-Herrera, Martin, Goya \& Ramos, 2015b). As a result, the cocoa rich807 diet improved the glycaemic control and insulin sensitivity in young ZDF rats. 808 Similarly, the effect of EC related to liver protection has also been evaluated. 809 Accordingly, obese diabetic $(\mathrm{db} / \mathrm{db})$ mice that were treated with EC $(0.25 \%$ in drinking 810 water, equivalent to $150 \mathrm{mg} / \mathrm{kg}$ body weight) during 15 weeks increased hepatic 811 antioxidant GSH content and total SOD activity, protecting the liver from the injury and 812 improving the $\mathrm{db} / \mathrm{db}$ mouse survival ( $\mathrm{Si}$ et al., 2011). Besides, it has also been 813 established that dietary EC (20 mg /Kg body weight, 8 weeks) alleviated high fructose 814 (HFr)-associated insulin resistance by modulating redox signalling and endoplasmic 815 reticulum stress in both liver and adipose tissue (Bettaieb et al., 2014). In particular, 816 NOX upregulation in HFr-fed rats, which was associated with increased liver and 817 adipose tissue oxidative damage (protein carbonyls), was prevented by EC 818 supplementation. Thus, EC-mediated NOX downregulation mitigated oxidative stress 819 decreasing the damage to cellular components and improving insulin sensitivity.

820 Finally, Ramirez-Sánchez et al. (2013) also examined the effect of EC on oxidative 821 stress in skeletal muscle (SkM) in both animal and human models of T2D. To this end, 822 obese/insulin resistant mice were administered with EC (1 $\mathrm{mg} / \mathrm{kg}$ body weight) by 823 gavage during 15 days. Likewise, T2D patients with previous heart failure consumed 824 during 3 months extra dark $60 \%$ cacao chocolate and cocoa beverages containing $18 \mathrm{~g}$ 
825 of natural cocoa powder (a total of $100 \mathrm{mg} \mathrm{EC/day).} \mathrm{At} \mathrm{the} \mathrm{end} \mathrm{of} \mathrm{the} \mathrm{study,} \mathrm{EC}$

826 treatment restored GSH levels, and both protein carbonylation and nitrotyrosilation 827 levels were normalised (carbonylation) or significantly reduced (nitrotyrosilation) in

828 SkM of T2D patients. Furthermore, key transcriptional factors (PGC1 $\alpha$ and FOXO1)

829 translocate into the nucleus leading to increased SOD and CAT protein expression

830 levels and activities. Similarly, in insulin resistant mice EC replicated the beneficial

831 effects found in humans. In summary, authors established that the actions exerted by EC

832 on oxidative stress regulatory elements likely contribute to the health benefits of cocoa

833 and prominently account for its antioxidant effects.

834

835 All previous evidences indicate that cocoa and its flavanols might play a beneficial role

836 on diabetes. However, the responsible mechanisms of their actions remain largely

837 unknown. In addition, more clinical trials are needed to clearly demonstrate the health

838 benefits of cocoa and its flavanols for diabetic patients and to dissipate clinical and

839 social doubts. In this line, it should be mentioned that few studies have reported effects

840 closely related to oxidative stress in diabetes, as most of them investigate markers

841 associated to the complications of this disease, such parameters related to CVD (blood

842 pressure, lipid profile, etc.). It should be also highlighted certain cocoa products could

843 worsen the glycaemic control in these patients due to their high caloric and sugar

844 contents. Therefore, as for cancer and CVD, it is essential to care about the contents of

845 sugar and fat in the cocoa product, as well as for the phenolic composition (type and

846 content), and the experimental concentrations employed.

847

848 6. Conclusions 
849 Oxidative stress plays a pivotal role in the pathogenesis of chronic disease. Cocoa

850 and its flavanols have been shown to have a strong antioxidant activity in

851 cultured cells, animal models and in humans. The modulatory effect exerted by

852 cocoa and its flavanols on the redox status and diverse cellular processes

853 (apoptosis, inflammation, etc.) has demonstrated that they would be able to

854 prevent and/or slow down the initiation-progression of different chronic diseases

855 related to oxidative stress, such as cancer, CVD and diabetes. Indeed, human

856 studies performed with patients have reported some positive changes in

857 biomarkers evaluating antioxidant status. However, it should be considered that

858 the preventive effects of cocoa and its flavanols against chronic diseases arise by

859 a number of mechanisms, including the antioxidant-related response, which affect

860 different aspects of the pathology. In addition it should be taken into account that

861 many features related to the mechanisms of action cocoa and its flavanols remain

862 to be elucidated, and that the phenolic composition of cocoa can highly differ

863 depending on its geographical origin as well as among processed and

864 unprocessed cocoa-products, as flavonoids decline during cocoa manufacturing

865 processes. It should also be noted that cocoa products with low fat, and no or low

866 sugar contents would be preferred, as high sugar and fat intakes are associated

867 with different diseases, such as cancer, CVD, diabetes, etc. Accurate

868 determination of the flavanol composition (type and content) and bioavailability

869 in cocoa products is required to precisely interpret its biological outcomes.

870 Careful mechanistic studies, as well as longer and well-controlled clinical trials

871 are needed to provide an integrated approach, and to discard possible side effects

872 associated to a prolonged cocoa intake. This will enable to fully understand the

873 potential of cocoa in terms of dose-effect, and therefore, the relevance of cocoa 
874 effects in the prevention and/or treatment of oxidative stress-related chronic 875 diseases.

876 


\section{Acknowledgements}

878 This work was supported by the grants AGL2015-67087-R and AGL2014-58205-

879 REDC from the Spanish Ministry of Science and Innovation (MICINN).

880

\section{Conflict of interest statement}

882 The authors have declared no conflict of interest.

883 


\section{References}

885 American Diabetes Association, A. D. A. (2014). Standards of medical care in diabetes886 2014. Diabetes Care, 37, S14-S80.

887

Anderson, R. F., Fisher, L. J., Hara, Y., Harris, T., Mak, W. B., Melton, L. D., et al. (2001). Green tea catechins partially protect DNA from .OH radical-induced strand breaks and base damage through fast chemical repair of DNA radicals. Carcinogenesis, 22, 1189-1193.

891

Andrés-Lacueva, C., Monagas, M., Khan, N., Izquierdo-Pulido, M., Urpi-Sarda, M., 892 Permanyer, J., et al. (2008). Journal of Agricultural and Food Chemistry, 56, 3111-3117.

Andujar, I., Recio, M. C., Giner, R. M., \& Rios, J. L. (2012). Cocoa polyphenols and 895 their potential benefits for human health. Oxidative Medicine Cell Longevity, 896 doi:10.1155/2012/906252.

897

Arranz, S., Valderas-Martinez, P., Chiva-Blanch, G., Casas, R., Urpi-Sarda, M., 898 Lamuela-Raventos, R. M., et al. (2013). Cardioprotective effects of cocoa: Clinical evidence from randomized clinical intervention trials in humans. Molecular Nutrition and Food Research, 57, 936-947.

901

Arts, C., Holmann, P., Bueno de Mesquita, H., Feskens, E., \& Kromhout, D. (2001). 902 Dietary catechins and epithelial cancer incidence: The Zutphen elderly study. 903 International Journal of Cancer, 92, 298-302.

904 Arts, I., Jacobs Jr, D., Gross, M., Harnack, L., \& Folsom, A. (2002). Dietary catechins 905 and cancer incidence among postmenopausal women: the Iowa Women's Health 906 Study (United States). Cancer Causes Control, 13, 373-382. 
907 Azam, S., Hadi, N., Khan, N., \& Hadi, S. (2004). Prooxidant property of green tea polyphenols epicatechin and epigallocatechin-3-gallate: implications for anticancer properties. Toxicology in Vitro, 18, 555-561.

Baba, S., Natsume, M., Yasuda, A., Nakamura, Y., Tamura, T., Osakabe, N., et al. (2007). Plasma LDL and HDL cholesterol and oxidized LDL concentrations are altered in normo- and hypercholesterolemic humans after intake of different levels of cocoa powder. Journal of Nutrition, 137, 1436-1441.

914 Bahia, P., Rattray, M., \& Williams, R. (2008). Dietary flavonoid (-)epicatechin stimulates phosphatidylinositol 3-kinase-dependent anti-oxidant response element activity and up-regulates glutathione in cortical astrocytes. Journal of Neurochemistry, 106, 2194-2204.

Basu-Modak, S., Gordon, M. J., Dobson, L. H., Spencer, J. P. E., Rice-Evans, C., \& Tyrrell, R. M. (2003). Epicatechin and its methylated metabolite attenuate UVAinduced oxidative damage to human skin fibroblasts. Free Radical Biology \& Medicine, 35, 910-921.

Bayard, V., Chamorro, F., Motta, J., \& Hollenberg, N. K. (2007). Does flavanol intake influence mortality from nitric oxide-dependent processes? Ischemic heart disease, stroke, diabetes mellitus, and cancer in Panama. International Journal of Medical Science, 4, 53-58.

Bedard, K., \& Krause, K.-H. (2007). The NOX family of ROS-generating NADPH oxidases: Physiology and pathophysiology. Physiological Reviews, 87, 245-313. Comparative study of commercially available cocoa products in terms of their bioactive composition. Food Research International, 42,707-716. 
931 Bensellam, M., Laybutt, D. R., \& Jonas, J.-C. (2012). The molecular mechanisms of

932

933

934

935

936

937

938

939

940

941

942

943

944

945

946

947

948

949

950

951

952

953

954 pancreatic b-cell glucotoxicity: recent findings and future research directions. Molecular and Cellular Endocrinology, 364, 1-27.

Bettaieb, A., Vazquez-Prieto, M. A., Rodriguez-Lanzi, C., Miatello, R. M., Haj, F. G., Fraga, C. G., et al. (2014). (-)-Epicatechin mitigates high-fructose associated insulin resistance by modulating redox signaling and endoplasmic reticulum stress. Free Radical Biology \& Medicine, 72, 247-256.

Boutron-Ruault, M. C., Senesse, P., Faivre, J., Chatelain, N., Belghiti, C., \& Méance, S. (1999). Foods as risk factors for colorectal cancer: a case-control study in Burgundy (France). European Journal of Cancer Prevention, 8, 229-235.

Brandes, R. P., Weissmann, N., \& Schroder, K. (2010). NADPHoxidases in cardiovascular disease. Free Radical Biology \& Medicine, 49, 687-706.

Carnevale, R., Loffredo, L., Pignatelli, P., Nocella, C., Bartimoccia, S., Di Santo, S., et al. (2012). Dark chocolate inhibits platelet isoprostanes via NOX2 downregulation in smokers. Journal of Thrombosis and Haemostasis, 10, 125-132.

Contreras, T. C., Ricciardi, E., Cremonini, E., \& Oteiza, P. I. (2015). ( )-Epicatechin in the prevention of tumor necrosis alpha-induced loss of Caco-2 cell barrier integrity. Archives of Biochemistry and Biophysics, 573, 84-91.

Cordero-Herrera, I., Martin, M. A., Goya, L., \& Ramos, S. (2015a). Cocoa flavonoids protect hepatic cells against high-glucose induced oxidative stress: Relevance of MAPKs. Molecular Nutrition and Food Research, 59, 597-609.

Cordero-Herrera, I., Martin, M. A., Goya, L., \& Ramos, S. (2015b). Cocoa intake ameliorates hepatic oxidative stress in young Zucker diabetic fatty rats. Food Research International, 69, 194-201. 
955 Chan, P., Cheng, J.-T., Tsai, J.-C., Lien, G.-S., Chen, F.-C., Kao, P.-F., et al. (2002).

956 Effect of catechin on the activity and gene expression of superoxide dismutase in cultured rat brain astrocytes. Neuroscience Letters, 328, 281-284.

958

959

960

961

962

963

964

965

966

967

968

969

970

971

972

973

974

975

976

977

978

979

Chen, L., Yang, X., Jiao, H., \& Zhao, B. (2002). Tea catechins protect against leadinduced cytotoxicity, lipid peroxidation, and membrane fluidity in HepG2 cells. Toxicological Sciences, 69, 149-156.

Cheng, Y. T., Wu, C. H., Ho, C. Y., \& Yen, G. C. (2013). Catechin protects against ketoprofen-induced oxidative damage of the gastric mucosa by up-regulating Nrf2 in vitro and in vivo. Journal of Nutritional Biochemistry, 24, 475-483.

Da Silva, M., Jaggers, G. K., Verstraeten, S. V., Erlejman, A. G., Fraga, C. G., \& Oteiza, P. I. (2012). Large procyanidins prevent bile-acid-induced oxidant production and membrane-initiated ERK1/2, p38, and Akt activation in Caco-2 cells. Free Radical Biology \& Medicine, 52, 151-159.

Davison, G., Callister, R., Williamson, G., Cooper, K. A., \& Gleeson, M. (2012). The effect of acute pre-exercise dark chocolate consumption on plasma antioxidant status, oxidative stress and immunoendocrine responses to prolonged exercise. European Journal of Nutrition, 51, 69-79.

Delgado, M. E., Haza, A. I., García, A., \& Morales, P. (2009). Myricetin, quercetin, (+)catechin and (-)-epicatechin protect against N-nitrosamines-induced DNA damage in human hepatoma cells. Toxicology in Vitro, 23, 1292-1297.

Dhalla, N. S., Temsah, R. M., \& Netticadan, T. (2000). Role of oxidative stress in cardiovascular diseases. Journal of Hypertension, 18, 655-673.

Eggler, A. L., Gay, K. A., \& Mesecar, A. D. (2008). Molecular mechanisms of natural products in chemoprevention: Induction of cytoprotective enzymes by Nrf2. Molecular Nutrition and Food Research, 52, S84-S94. 
980 Engler, M. B., Engler, M. M., Chen, C. Y., Malloy, M. J., Browne, A., Chiu, E. Y., et

981

982

983

984

985

986

987

988

989

990

991

992

993

994

995

996

997

998

999

1000

1001

1002

1003

1004

al. (2004). Flavonoid-rich dark chocolate improves endothelial function and increases plasma epicatechin concentrations in healthy adults. Journal of the American College of Nutrition, 23, 197-204.

Erlejman, A. G., Fraga, C. G., \& Oteiza, P. I. (2006). Procyanidins protect Caco-2 cells from bile acid- and oxidant-induced damage. Free Radical Biology \& Medicine, $41,1247-1256$

Erlejman, A. G., Jaggers, G., Fraga, C. G., \& Oteiza, P. I. (2008). TNF $\alpha$-induced NF-кB activation and cell oxidant production are modulated by hexameric procyanidins in Caco-2 cells. Archives of Biochemistry and Biophysics, 476, 186-195.

Espinosa-Diez, C., Miguel, V., Mennerich, D., Kietzmann, T., Sánchez-Pérez, P., Cadenas, S., et al. (2015). Antioxidant responses and cellular adjustments to oxidative stress. Redox Biology, 6, 183-197.

Estany, S., Palacio, J. R., Barnadas, R., Sabes, M., Iborra, A., \& Mart'1nez, P. (2007). Antioxidant activity of $\mathrm{N}$-acetylcysteine, flavonoids and alpha-tocopherol on endometrial cells in culture. Journal of Reproductive Immunology, 75, 1-10.

European Food Safety Authority (EFSA). (2012). Scientific opinion on the substantiation of a health claim related to cocoa flavanols and maintenance of normal endothelium-dependent vasodilation pursuant to Article 13(5) of Regulation (EC) No 1924/20061. EFSA J; 10:2809.

International Federation of Diabetes. (2014). IDF Diabetes Atlas. 6th.

Fernández-Millán, E., Cordero-Herrera, I., Ramos, S., Escrivá, F., Alvarez, C., Goya, L., et al. (2015). Cocoa-rich diet attenuates beta cell mass loss and function in young Zucker diabetic fatty rats by preventing oxidative stress and beta cell apoptosis. Molecular Nutrition of Food Reseacrh, 59, 820-824. 
1005 Fernández-Millán, E., Ramos, S., Alvarez, C., Bravo, L., Goya, L., \& Martin, M. A. (2014). Microbial phenolic metabolites improve glucose-stimulated insulin secretion and protect pancreatic beta cells against tert-butylhydroperoxideinduced toxicity via ERKs and PKC pathways. Food Chemical Toxicology, 66,

1010 Finkel, T., \& Holbrook, N. (2000). Oxidants, oxidative stress and the biology of ageing. Nature, 408, 239-247.

1012 Folli, F., Corradi, D., Fanti, P., Davalli, A., Paez, A., Giaccari, A., et al. (2011). The role of oxidative stress in the pathogenesis of type 2 diabetes mellitus micro- and macrovascular complications: avenues for a mechanistic-based therapeutic approach. Current Diabetes Reviews, 7, 313-324.

Fraga, C. G. (2007). Plant polyphenols: how to translate their in vitro antioxidant actions to in vivo conditions. IUBMB Life, 59, 308-315.

Galleano, M., Oteiza, P. I., \& Fraga, C. G. (2009). Cocoa, chocolate, and cardiovascular disease. Journal of Cardiovascular Pharmacology, 54, 483-490.

1024 Giacco, F., \& Brownlee, M. (2010). Oxidative stress and diabetic complications. Circulation Research, 107, 1058-1070.

1026 Giacometti, J., Muhvic', D., Pavletic', A., \& Đudaric, D. (2016). Cocoa polyphenols exhibit antioxidant, antiinflammatory, anticancerogenic, and antinecrotic activity in carbon tetrachlorideintoxicated mice. Journal of Functional Foods, 23, 177187. 
1030 Giannandrea, F. (2009). Correlation analysis of cocoa consumption data with worldwide

1031

1032

1033

1034

1035

1036

1037

1038

1039

1040

1041

1042

1043

1044

1045

1046

1047

1048

1049

1050

1051

1052

1053

1054 incidence rates of testicular cancer and hypospadias. International Journal of Environmental Research and Public Health, 6, 568-578.

Gómez-Guzmán, M., Jimenez, R., Sanchez, M., Romero, M., O’Valle, F., LopezSepulveda, R., et al. (2011). Chronic (2)-epicatechin improves vascular oxidative and inflammatory status but not hypertension in chronic nitric oxidedeficient rats. British Journal of Nutrition, 106, 1337-1348.

Gomez-Guzman, M., Jimenez, R., Sanchez, M., Zarzuelo, M. J., Galindo, P., Quintela, A. M., et al. (2012). Epicatechin lowers blood pressure, restores endothelial function, and decreases oxidative stress and endothelin-1 and NADPH oxidase activity in DOCA-salt hypertension. Free Radical Biology \& Medicine, 52, 7079.

Granado-Serrano, A., Martin, M., Goya, L., Bravo, L., \& Ramos, S. (2009a). Timecourse regulation of survival pathways by epicatechin on HepG2 cells. Journal of Nutritional Biochemistry, 20, 115-124.

Granado-Serrano, A., Martin, M., Izquierdo-Pulido, M., Goya, L., Bravo, L., \& Ramos, S. (2007). Molecular mechanisms of (-)-epicatechin and chlorogenic acid on the regulation of the apoptotic and survival/proliferation pathways in a human hepatoma cell line. Journal of Agricultural and Food Chemistry, 55, 2020-2027.

Granado-Serrano, A. B., Martín, M. A., Bravo, L., Goya, L., \& Ramos, S. (2009b). A diet rich in cocoa attenuates N-nitrosodiethylamine-induced liver injury in rats. Food Chemical Toxicology, 47, 2499-2506.

Granado-Serrano, A. B., Martín, M. A., Haegeman, G., Goya, L., \& Bravo, L. (2010). Epicatechin induces NF-kB, activator protein-1 (AP-1) and nuclear transcription factor erythroid 2p45-related factor-2 (Nrf2) via phosphatidylinositol-3- 

kinase/protein kinase $\mathrm{B}(\mathrm{PI} 3 \mathrm{~K} / \mathrm{AKT})$ and extracellular regulated kinase (ERK) signalling in HepG2 cells. British Journal of Nutrition, 103, 168-179.

1057

Grassi, D., Desideri, G., \& Ferri, C. (2013). Protective effects of dark chocolate on endothelial function and diabetes. Current Opinion in Clinical Nutrition and Metabolic Care, 16, 662-668.

1060 Greenberg, J. A. (2015). Chocolate intake and diabetes risk. Clinical Nutrition, 34, 129133.

1062 Gu, L., House, S. E., Wu, X., Ou, B. \& Prior, R.L. (2006). Procyanidin and catechin contents and antioxidant capacity of cocoa and chocolate products. Journal of Agricultural and Food Chemistry, 54, 4057-4061.

Hatano, T., Miyatake, H., Natsume, M., Osakabe, N., Takizawa, T., Ito, H., et al. (2002). Proanthocyanidin glycosides and related polyphenols from cacao liquor and their antioxidant effects. Phytochemistry, 59, 749-758.

1068

Haza, A. I., \& Morales, P. (2011). Effects of (+)catechin and (-)epicatechin on heterocyclic amines-induced oxidative DNA damage. Journal of Applied Toxicology, 31, 53-62.

Hermann, F., Spieker, L. E., Ruschitzka, F., Sudano, I., Hermann, M., Binggeli, C., et al. (2006). Dark chocolate improves endothelial and platelet function. Heart, 92, 119-120.

Higginbotham, E., \& Taub, P. R. (2015). Cardiovascular benefits of dark chocolate? Current Treatment Options in Cardiovascular Medicine, 17, 54. al. (2011). The biological relevance of direct antioxidant effects of polyphenols for cardiovascular health in humans is not established. Journal of Nutrition, 141, 989S-1009S. 
1080 Hong, M. Y., Nulton, E., Shelechi, M., Hernández, L. M., \& Nemoseckseck, T. (2013).

1081

1082

1083

1084

1085

1086

1087

1088

1089

1090

1091

1092

1093

1094

1095

1096

1097

1098

1099

1100

1101

1102 Effects of dark chocolate on azoxymethane-induced colonic aberrant crypt foci. Nutrition \& Cancer, 65, 677-685.

Huige, L., Horke, S., \& Förstermann, U. (2013). Oxidative stress in vascular disease and its pharmacological prevention. Trends in Pharmacological Sciences, 34, 313-319.

Ibero-Baraibar, I., Abete, I., Navas-Carretero, S., Massis-Zaid, A., Martinez, J. A., \& Zulet, M. A. (2014). Oxidised LDL levels decreases after the consumption of ready-to-eat meals supplemented with cocoa extract within a hypocaloric diet. Nutrition, Metabolism and Cardiovascular Diseases, 24, 416-422.

Jeon, S. E., Choi-Kwon, S., Park, K. A., Lee, H. J., Park, M. S., Lee, J. H., et al. (2003). Dietary supplementation of (1)-catechin protects against UVB-induced skin damage by modulating antioxidant enzyme activities. Photodermatology Photoimmunology and Photomedicine, 19, 235-241.

Kerimi, A., \& Williamson, G. (2015). The cardiovascular benefits of dark chocolate. Vascular Pharmacology, 71 11-15.

Khan, N., Monagas, M., Andres-Lacueva, C., Casas, R., Urpi-Sarda, M., LamuelaRaventos, R. M., et al. (2012). Regular consumption of cocoa powder with milk increases HDL cholesterol and reduces oxidized LDL levels in subjects at highrisk of cardiovascular disease. Nutrition, Metabolism and Cardiovascular Diseases, 22, 1046-1053.

Kim, Y., Keogh, J. B., \& Clifton, P. M. (2016). Polyphenols and glycemic control. Nutrients, 8, 17, doi:10.3390/nu8010017. 
1103 Kim, J., Kim, J., Shim, J., Lee, C. Y., Lee, K.W. \& Lee, H.J. (2014). Cocoa phytochemicals: recent advances in molecular mechanisms on health. Critical Reviews in Food Science and Nutrition, 54, 1458-1472.

1106 Kwok, C. S., Boekholdt, S. M., Lentjes, M. A., Loke, Y. K., Luben, R. N., Yeong, J. K., 1107 et al. (2015). Habitual chocolate consumption and risk of cardiovascular disease 1108 among healthy men and women. Heart, 1279-12787.

1109 Lambert, J. D., \& Elias, R. J. (2010). The antioxidant and pro-oxidant activities of green 1110 tea polyphenols: A role in cancer prevention. Archives of Biochemistry and $1111 \quad$ Biophysics, 501, 65-72.

1112 Lapidot, T., Walker, M., \& Kanner, J. (2002). Antioxidant and prooxidant effects of 1113 phenolics on pancreatic beta-cells in vitro. Journal of Agricultural and Food $1114 \quad$ Chemistry, 50, 7220-7225.

1115 Lee, K. W., Kim, Y. J., Lee, H. J., \& Lee, C. Y. (2003). Cocoa has more phenolic phytochemicals and a higher antioxidant capacity than teas and red wine. Journal of Agricultural and Food Chemistry, 51, 7292-7295.

1118 Litterio, M. C., Jaggers, G., Sagdicoglu, C. G., Adamo, A. M., Costa, M. A., Oteiza, P. 1119 I., et al. (2012). Blood pressure-lowering effect of dietary (-)-epicatechin 1120 administration in L-NAME-treated rats is associated with restored nitric oxide levels. Free Radical Biology \& Medicine, 53, 1894-1902.

1122 Litterio, M. C., Vazquez Prieto, M. A., Adamo, A. M., Elesgaray, R., Oteiza, P. I., 1123 Galleano, M., et al. (2015). (-)-Epicatechin reduces blood pressure increase in 1124 high-fructose-fed rats: effects on the determinants of nitric oxide bioavailability. Journal of Nutritional Biochemistry, 26, 745-751. 
1126 Loffredo, L., Carnevale, R., Perri, L., Catasca, E., Augelletti, T., Cangemi, R., et al.

1127 (2011). NOX2-mediated arterial dysfunction in smokers: acute effect of dark $1128 \quad$ chocolate. Heart, 97, 1776-1781.

1129 Loffredo, L., Perri, L., Catasca, E., Pignatelli, P., Brancorsini, M., Nocella, C., et al. 1130 (2014). Dark chocolate acutely improves walking autonomy in patients with 1131 peripheral artery disease. Journal of the American Heart Association, 3, $1132 \mathrm{e} 001072$.

1133 Lotito, S. B., \& Frei, B. (2006). Consumption of flavonoid-rich foods and increased plasma antioxidant capacity in humans: Cause, consequence, or epiphenomenon? Free Radical Biology \& Medicine, 41, 1727-1746.

1136 Martin, M. A., Fernández-Millán, E., Ramos, S., Bravo, L., \& Goya, L. (2014). Cocoa 1137 flavonoid epicatechin protects pancreatic beta cell viability and function against oxidative stress. Molecular Nutrition and Food Research, 58, 447-466.

1139 Martín, M. A., Goya, L., \& Ramos, S. (2013). Potential for preventive effects of cocoa $1140 \quad$ and cocoa polyphenols in cancer. Food Chemistry Toxicology, 56, 336-351.

1141 Martín, M. A., Goya, L., \& Ramos, S. (2016). Antidiabetic actions of cocoa flavanols. $1142 \quad$ Molecular Nutrition and Food Research, doi: 10.1002/mnfr.201500961.

1143 Martín, M. A., Granado-Serrano, A. B., Ramos, S., Izquierdo-Pulido, M., Bravo, L., \& 1144 Goya, L. (2010a). Cocoa flavonoids up-regulate antioxidant enzyme activity via 1145 the ERK1/2 pathway to protect against oxidative stress-induced apoptosis in 1146 HepG2 cells. Journal of Nutritional Biochemistry, 21, 196-205.

1147 Martin, M. A., Ramos, S., Cordero-Herrera, I., Bravo, L., \& Goya, L. (2013). Cocoa 1148 phenolic extract protects pancreatic beta cells against oxidative stress. Nutrients, $1149 \quad 5,2955-2968$. 
1150 Martín, M. A., Ramos, S., Mateos, R., Granado-Serrano, A. B., Izquierdo-Pulido, M., 1151 Bravo, L., et al. (2008). Protection of human HepG2 cells against oxidative 1152 stress by cocoa phenolic extract. Journal of Agricultural and Food Chemistry, $1153 \quad 56,7765-7772$.

1154 Martín, M. A., Ramos, S., Mateos, R., Izquierdo-Pulido, M., Bravo, L., \& Goya, L. 1155 (2010b). Protection of human HepG2 cells against oxidative stress by the 1156 flavonoid epicatechin. Phytotherapy Research, 24, 503-509.

1157 Masella, R., Di Benedetto, R., Vari, R., Filesi, C., \& Giovannini, C. (2005). Novel 1158 mechanisms of natural antioxidant compounds in biological systems: 1159 involvement of glutathione and glutathione-related enzymes. Journal of $1160 \quad$ Nutritional Biochemistry, 16, 577-586.

1161 Maskarinec, G. (2009). Cancer protective properties of cocoa: a review of the epidemiologic evidence. Nutrition \& Cancer, 61, 573-579.

1163 McKelvey, W., Greenland, S., \& Sandler, R. S. (2000). A second look at the relation 1164 between colorectal adenomas and consumption of foods containing partially 1165 hydrogenated oils. Epidemiology, 11, 469-473.

1166 Mellor, D. D., Madden, L. A., Smith, K. A., Kilpatrick, E. S., \& Atkin, S. L. (2013). 1167 High-polyphenol chocolate reduces endothelial dysfunction and oxidative stress 1168 during acute transient hyperglycaemia in Type 2 diabetes: a pilot randomized 1169 controlled trial. Diabetic Medicine, 30, 478-483.

1170 Miller, K. B., Hurst, W. J., Flannigan, N., Ou, B., Lee, C. Y., Smith, N., et al. (2009). 1171 Survey of commercially available chocolate- and cocoa-containing products in 1172 the United States. 2. Comparison of flavan- 3-ol content with nonfat cocoa 1173 solids, total polyphenols, and percent cacao. Journal of Agricultural and Food $1174 \quad$ Chemistry, 57, 9169-9180. 
1175 Monga, J., Aggarwal, V., Suthar, S. K., Monika, Nongalleimac, K., \& Sharma, M. 1176 (2014). Topical (+)-catechin emulsified gel prevents DMBA/TPA-induced 1177 squamous cell carcinoma of the skin by modulating antioxidants and 1178 inflammatory biomarkers in BALB/c mice. Food \& Function, 5, 3197-3207.

1179 Murakami, C., Hirakawa, Y., Inui, H., Nakano, Y., \& Yoshida, H. (2002). Effect of tea 1180 catechins on cellular lipid peroxidation and cytotoxicity in HepG2 cells. 1181 Bioscience, Biotechnology, and Biochemistry, 66, 1559-1562.

1182 Mursu, J., Voutilainen, S., Nurmi, T., Rissanen, T. H., Virtanen, J. K., Kaikkonen, J., et 1183 al. (2004). Dark chocolate consumption increases HDL cholesterol concentration 1184 and chocolate fatty acids may inhibit lipid peroxidation in healthy humans. Free $1185 \quad$ Radical Biology \& Medicine, 37, 1351-1359.

1186 Nakagawa, H., Hasumi, K., Woo, J., Nagai, K., \& Wachi, M. (2004). Generation of 1187 hydrogen peroxide primarily contributes to the induction of $\mathrm{Fe}(\mathrm{II})$-dependent 1188 apoptosis in Jurkat cells by (-)-epigallocatechin gallate. Carcinogenesis, 25, $1189 \quad 1567-1574$.

1190 Nanetti, L., Raffaelli, F., Tranquilli, A. L., Fiorini, R., Mazzanti, L., \& Vignini, A. 1191 (2012). Effect of consumption of dark chocolate on oxidative stress in 1192 lipoproteins and platelets in women and in men. Appetite, 58, 400-405.

1193 Natsume, M., Osakabe, N., Yasuda, A., Baba, S., Tokunaga, T., Kondo, K., et al. 1194 (2004). In vitro antioxidative activity of (-)-epicatechin glucuronide metabolites 1195 present in human and rat plasma. Free Radical Research, 38, 1341-1348.

1196 Ohno, M., Sakamoto, K. Q., Ishizuka, M., \& Fujita, S. (2009). Crude cacao Theobroma 1197 cacao extract reduces mutagenicity induced by benzo[a]pyrene through inhibition of CYP1A activity in vitro. Phytotherapy Research, 23, 1134-1139. 
1199 Oleaga, C., Garcia, M., Sole', A., C.J., C., Izquierdo-Pulido, M., \& Noe, V. (2012). CYP1A1 is overexpressed upon incubation of breast cancer cells with a polyphenolic cocoa extract. European Journal of Nutrition, 51, 465-476.

1202 Ottaviani, J. I., Carrasquedo, F., Keen, C. L., Lazarus, S. A., Schmitz, H. H., \& Fraga, C. G. (2002). Influence of flavan-3-ols and procyanidins on UVC-mediated formation of 8-oxo-7,8-dihydro-20-deoxyguanosine in isolated DNA. Archives

Pal, S., Dey, S. K., \& Saha, C. (2014). Inhibition of catalase by tea catechins in free and cellular state: a biophysical approach. PLOSOne, 9, e102460.

1208 Pandurangan, A. K., Saadatdoust, Z., Esa, N. M., Hamzah, H., \& Ismail, A. (2015).

1209 Dietary cocoa protects against colitisassociated cancer by activating the $1210 \quad$ Nrf2/Keap1 pathway. BioFactors, 41, 1-14.

1211 Papiez, M., Baran, J., Bukowska-Strakova, K., \& Krosniak, M. (2011). Epicatechin administration leads to necrotic cell death of rat leukaemia promyelocytes in vivo. In vivo, 25, 29-34.

1214 Papiez, M. A., Bukowska-Strakova, K., Krzysciak, W., \& Baran, J. (2012). (-)Epicatechin enhances etoposide-induced antileukaemic effect in rats with acute myeloid leukaemia. Anticancer Research, 32, 2905-2914.

1217 Parsaeyan, N., Mozaffari-Khosravi, H., Absalan, A., \& Mozayan, M. R. (2014). Beneficial effects of cocoa on lipid peroxidation and inflammatory markers in type 2 diabetic patients and investigation of probable interactions of cocoa active ingredients with prostaglandin synthase-2 (PTGS-2/COX-2) using virtual analysis. Journal of Diabetes \& Metabolic Disorders, 13, 30. 
1222 Parvez, S., Tabassum, H., Rehman, H., Banerjee, B. D., Athar, M., \& Raisuddin, S.

1223

1224

1225

1226

1227

1228

1229

1230

1231

1232

1233

1234

1235

1236

1237

1238

1239

1240

1241

1242 Rein, D., Lotito, S., Holt, R., Keen, C., Schmitz, H., \& Fraga, C. (2000a). Epicatechin in perturbations in mice. Toxicology, 225, 109-118.

Peterson, J., Lagiou, P., Samoli, E., Lagiou, A., Katsouyanni, K., La Vecchia, C., et al. (2003). Flavonoid intake and breast cancer risk: a case-control study in Greece. British Journal of Cancer, 89, 1255-1259.

Piotrkowski, B., Calabró, V., Galleano, M., \& Fraga, C. G. (2015). (-)-Epicatechin prevents alterations in the metabolism of superoxide anion and nitric oxide in the hearts of L-NAME-treated rats. Food \& Function, 6, 155-161.

Ramirez-Sanchez, I., Taub, P. R., Ciaraldi, T. P., Nogueira, L., Coe, T., Perkins, G., et al. (2013). (-)-Epicatechin rich cocoa mediated modulation of oxidative stress regulators in skeletal muscle of heart failure and type 2 diabetes patients. International Journal of Cardiology, 168, 3982-3990.

Ramiro-Puig, E., Casadesus, G., Lee, H. G., Zhu, X., McShea, A., Perry, G., et al. (2009). Neuroprotective effect of cocoa flavonids on in vitro oxidative stress. European Journal of Nutrition, 48, 54-61.

Ramos, S. (2007). Effects of dietary flavonoids on apoptotic pathways related to cancer chemoprevention. Journal of Nutritional Biochemistry, 18, 427-442.

Ramos, S. (2008). Cancer chemoprevention and chemotherapy: dietary polyphenols and signalling pathways. Molecular Nutrition and Food Research, 52, 507-526. (2006). Catechin prevents tamoxifen-induced oxidative stress and biochemical

1243 human plasma: In vivo determination and effect of chocolate consumption on plasma oxidation status. Journal of Nutrition, 130, 2109S-2114S. 
1245 Rein, D., Paglieroni, T. G., Pearson, D. A., Wun, T., Schmitz, H. H., Gosselin, R., et al. (2000b). Cocoa and wine polyphenols modulate platelet activation and function. Journal of Nutrition, 130, 2120S-2126S.

Ríos, J. L., Francini, F., \& Schinella, G. R. (2015). Natural products for the treatment of type 2 diabetes mellitus. Planta Medica, 81, 975-994.

1250 Robertson, R. P. (2010). Antioxidant drugs for treating beta-cell oxidative stress in type 2 diabetes: glucose-centric versus insulin-centric. Discovery Medicine, 9, 132-

Rodgers, E. H., \& Grant, M. H. (1998). The effect of the flavonoids, quercetin, myricetin and epicatechin on the growth and enzyme activities of MCF7 human breast cancer cells Chemico-Biological Interactions, 116, 213-228.

Rodriguez-Ramiro, I., Martin, M. A., Ramos, S., Bravo, L., \& Goya, L. (2011a). Comparative effects of dietary flavanols on antioxidant defences and their response to oxidant-induced stress on Caco2 cells. European Journal of Nutrition, 50, 313-322.

Rodriguez-Ramiro, I., Ramos, S., Bravo, L., Goya, L., \& Martín, M. A. (2011b). Procyanidin B2 and a cocoa polyphenolic extract inhibit acrylamide-induced apoptosis in human Caco-2 cells by preventing oxidative stress and activation of JNK pathway. Journal of Nutritional Biochemistry, 22, 1186-1194.

Rodrıguez-Ramiro, I., Ramos, S., Bravo, L., Goya, L., \& Martín, M. A. (2012). Procyanidin B2 induces Nrf2 translocation and glutathione S-transferase P1 expression via ERKs and p38-MAPK pathways and protect human colonic cells L., et al. (2013). Cocoa polyphenols prevent inflammation in the colon of 2 

of Nutrition, 110, 206-215.

1272 Rodriguez-Ramiro, I., Ramos, S., Lopez-Oliva, E., Agis-Torres, A., Gomez-Juaristi, M., Mateos, R., et al. (2011c). Cocoa-rich diet prevents azoxymethane-induced colonic preneoplastic lesions in rats by restraining oxidative stress and cell proliferation and inducing apoptosis. Molecular Nutrition and Food Research,

Rouillier, P., Senesse, P., Cottet, V., Valleau, A., Faivre, J., \& Boutron-Ruault, M. C. (2005). Dietary patterns and the adenomacarcinoma sequence of colorectal cancer. European Journal of Nutrition, 44, 311-318.

1280 Ruijters, E. J. B., Weseler, A. R., Kicken, C., Haenen, G. R. M. M., \& Bast, A. (2013). The flavanol(-)-epicatechin and its metabolites protect against oxidative stress in primary endothelial cells via a direct antioxidant effect. European Journal of Pharmacology, 715, 147-153.

Sakano, K., Mizutani, M., Murata, M., Oikawa, S., Hiraku, Y., \& Kawanishi, S. (2005).

Sánchez-Rabaneda, F., Jáuregui, O., Casals, I., Andrés-Lacueva, C., Izquierdo-Pulido,

Sarriá, B., Mateos, R., Sierra-Cinos, J. L., Goya, L., García-Diz, L., \& Bravo, L. (2012). Hypotensive, hypoglycaemic and antioxidant effects of consuming a cocoa product in moderately hypercholesterolemic humans. Food \& Function, 3, 8678774. 
1295 Schewe, T., \& Sies, H. (2005). Myeloperoxidase-induced lipid peroxidation of LDL in the presence of nitrite. Protection by cocoa flavanols. Biofactors, 24, 49-58.

1297 Schewe, T., Steffen, Y., \& Sies, H. (2008). How do dietary flavanols improve vascular function? A position paper. Archives of Biochemistry and Biophysics, 476, 102106.

1300 Shahidi, F., \& Ambigaipalan, P. (2015). Phenolics and polyphenolics in foods, beverages and spices: Antioxidant activity and health effects -A review. Journal

Si, H., Fu, Z., Babu, P. V., Zhen, W., Leroith, T., Meaney, M. P., et al. (2011). Dietary epicatechin promotes survival of obese diabetic mice and Drosophila melanogaster. Journal of Nutrition, 141, 1095-1100.

Sies, H., Schewe, T., Heiss, C., \& Kelm, M. (2005). Cocoa polyphenols and inflammatory mediators. American Journal of Clinical Nutrition, 81, 304S$312 \mathrm{~S}$.

Sinha, M., Das, D. K., Manna, K., Datta, S., Ray, T., Sil, A. K., et al. (2012).

1312 Somasundaram, S., Edmund, N. A., Moore, D. T., Small, G. W., Shi, Y. Y. \& Orlowski, R. Z. (2002). Dietary curcumin inhibits chemotherapy-induced apoptosis in models of human breast cancer. Cancer Research, 62, 3868-3875.

1315 Spadafranca, A., Martinez Conesa, C., Sirini, S., \& Testolin, G. (2010). Effect of dark chocolate on plasma epicatechin levels, DNA resistance to oxidative stress and total antioxidant activity in healthy subjects. British Journal of Nutrition, 103, $1008-1114$. 
1319 Steffen, Y., Gruber, C., Schewe, T., \& Sies, H. (2008). Mono-O-methylated flavanols and other flavonoids as inhibitors of endothelial NADPH oxidase. Archives of Biochemistry and Biophysics, 469, 209-219.

Steinberg, D. (1997). Low density lipoprotein oxidation and its pathobiological significance. Journal of Biological Chemistry, 272, 20963-20966.

1324 Stote, K. S., Clevidence, B. A., Novotny, J. A., Henderson, T., Radecki, S. V., \& Baer, D. J. (2012). Effect of cocoa and green tea on biomarkers of glucose regulation, oxidative stress, inflammation and hemostasis in obese adults at risk for insulin resistance. European Journal of Clinical Nutrition, 66, 1153-1159.

Szeto, Y. T., \& Benzie, I. F. (2002). Effects of dietary antioxidants on human DNA ex vivo. Free Radical Research, 36, 113-118.

1330 Tabassum, H., Parvez, S., Rehman, H., Banerjee, B. D., \& Raisuddin, S. (2007). Catechin as an antioxidant in liver mitochondrial toxicity: Inhibition of tamoxifen-induced protein oxidation and lipid peroxidation. Journal of

1334 Tousoulis, D., Simopoulou, C., Papageorgiou, N., Oikonomou, E., Hatzis, G., Siasos, G., et al. (2014). Endothelial dysfunction in conduit arteries and in microcirculation. Novel therapeutic approaches. Pharmacology \& Therapeutics, $144,253-267$.

Valko, M., Leibfritz, D., Moncol, J., Cronin, M. T. D., Mazura, M., \& Telser, J. (2007). Free radicals and antioxidants in normal physiological functions and human disease. International Journal of Biochemistry and Cell Biology, 39, 44-84.

Verstraeten, S. V., Hammerstone, J. F., Keen, C. L., Fraga, C. G., \& Oteiza, P. I. (2005). Antioxidant and membrane effects of procyanidin dimers and trimers 
isolated from peanut and cocoa. Journal of Agricultural and Food Chemistry, 53, 5041-5048

1345 Vinson, J. A., Proch, J., \& Zubik, L. (1999). Phenol antioxidant quantity and quality in

1363 Yang, B.-Y., Zhang, X.-Y., Guan, S.-W., \& Hua, Z.-C. (2015). Protective effect of procyanidin B2 against CCl4-induced acute liver injury in mice. Molecules, 20,

1366 Yang, B., \& Rizzo, V. (2007). TNF-alpha potentiates protein-tyrosine nitration through activation of NADPH oxidase and eNOS localized in membrane rafts and 
1370 
1371 Legends to figures

1372

1373 Figure 1. Chemical structures of main flavanols present in cocoa

1374

1375 Figure 2. Reactions involved in RONS formation leading to oxidative damage of

1376 macromolecules (proteins, lipids, DNA). Hydrogen peroxide is detoxified by the

1377 enzymes glutathione-S-transferase (GST) or glutathione peroxidase (GPx), which

1378 requires reduced glutathione (GSH) and generates oxidised glutathione (GSSG). GSSG

1379 is reduced back to GSH by the enzyme glutathione reductase (GR) which uses NADPH

1380 as the electron donor. Superoxide anion radical is formed by the reduction of molecular

1381 oxygen mediated by $\mathrm{NAD}(\mathrm{P}) \mathrm{H}$ oxidases and xanthine oxidase, or non-enzymatically

1382 (semi-ubiquinone compound of the mitochondrial electron transport chain). Superoxide

1383 radical is dismutated by the superoxide dismutase (SOD) to hydrogen peroxide. (RSG:

1384 GSH conjugated with an electrophilic compound). Adapted from Valko et al., 2007 and

1385 Espinosa-Diez et al., 2015. 
Table 1. Composition in phenolic compounds and flavanol content of cocoa.

\title{
Flavanols
}

(-)-Epicatechin $(0.12-2.83 \mathrm{mg} / \mathrm{g})$

(+)-Catechin (0.040-0.90 mg/g)

Epigallocatechin $^{\mathrm{a}}$

Epigallocatechin-3-gallate ${ }^{\mathrm{a}}$

Procyanidin B1 (epicatechin- $(4 \beta \rightarrow 8)$-catechin) $(0.035 \mathrm{mg} / \mathrm{g})$

Procyanidin B2 (epicatechin- $(4 \beta \rightarrow 8)$-epicatechin) $(0.13-0.97 \mathrm{mg} / \mathrm{g})$

Procyanidin B2-O-gallate (epicatechin-3-O-gallate- $(4 \beta \rightarrow 8)$ epicatechin) ${ }^{\mathrm{a}}$

Procyanidin B2-3,3-di- $O$-gallate (epicatechin-3-O-gallate-( $4 \beta \rightarrow 8)$ epicatechin-3-O-gallate $)^{\mathrm{a}}$

Procyanidin B3 (catechin- $(4 \alpha \rightarrow 8)-$ catechin $^{\mathrm{a}}$

Procyanidin B4 (catechin- $(4 \alpha \rightarrow 8)$-epicatechin $)^{\mathrm{a}}$

Procyanidin B4- $O$-gallate (catechin- $(4 \beta \rightarrow 8)$-epicatechin-3-O-gallate $)^{\mathrm{a}}$

Procyanidin C1 (epicatechin- $(4 \beta \rightarrow 8)$-epicatechin- $(4 \beta \rightarrow 8)$-epicatechin) ${ }^{\mathrm{a}}$

Procyanidin D (epicatechin- $(4 \beta \rightarrow 8)$-epicatechin- $(4 \beta \rightarrow 8)$-epicatechin$(4 \beta \rightarrow 8)$-epicatechin $)^{\mathrm{a}}$

\section{Flavones}

\author{
Luteolin $^{\mathrm{a}}$ \\ Luteolin-7-O-glucoside $^{\text {a }}$ \\ Orientin (luteolin-8-C-glucoside) ${ }^{\mathrm{a}}$ \\ Isoorientin (luteolin-6-C-glucoside) ${ }^{\mathrm{a}}$ \\ Apigenin $^{\mathrm{a}}$ \\ Vitexin (apigenin-8-C-glucoside) ${ }^{\mathrm{a}}$ \\ Isovitexin (apigenin-6-C-glucoside) ${ }^{\mathrm{a}}$
}

\section{Flavanones}

\author{
Naringenin ${ }^{\mathrm{a}}$ \\ Prunin (naringenin-7-O-glucoside) ${ }^{\mathrm{a}}$ \\ Hesperidin $^{\mathrm{a}}$ \\ Eriodictyol $^{\mathrm{a}}$
}

\section{Flavonols}

Quercetin (0.00021-0.00325 mg/g)

Quercetin-3-O-arabinoside (0.0021-0.040 mg/g)

Isoquercitrin (quercetin-3-O-glucoside) $(0.0040-0.043 \mathrm{mg} / \mathrm{g}$ )

Hyperoside (quercetin-3-O-galactoside) ${ }^{\mathrm{a}}$

\section{Anthocyanidins}

Cyanidin $^{\mathrm{a}}$

3- $\alpha$-L-arabinosidyl cyanidin ${ }^{\mathrm{a}}$

3- $\beta$-D-arabinosidyl cyanidin ${ }^{\mathrm{a}}$

3- $\beta$-D-galactosidyl cyanidin ${ }^{\mathrm{a}}$ 


\section{Phenolic acids}

Vanillic acid ${ }^{\mathrm{a}}$

Syringic acid $^{\mathrm{a}}$

Chlorogenic acid ${ }^{\mathrm{a}}$

Phlorectic acid ${ }^{\mathrm{a}}$

Coumaric acid $^{\mathrm{a}}$

Caffeic acid $^{\mathrm{a}}$

Ferulic acid ${ }^{\mathrm{a}}$

Phenylacetic acid

${ }^{a}$ n.a., not applicable. Phenolic compound identified at trace levels. 
Table 2. Antioxidant effects of cocoa and cocoa flavonoids on experimental cancer models ${ }^{\mathrm{a}}$

\begin{tabular}{|c|c|c|c|c|c|}
\hline Tissue & $\begin{array}{l}\text { Experimental } \\
\text { model }\end{array}$ & Treatment (dose) & Duration $^{\mathrm{a}}$ & Main effects ${ }^{b}$ & Reference \\
\hline \multirow[t]{3}{*}{ Breast } & MCF-7 cells & $\begin{array}{l}\text { Cocoa extract } \\
(250 \mathrm{ng} / \mu \mathrm{L})\end{array}$ & $24 \mathrm{~h}$ & $\uparrow$ CYP1A1 mRNA & (Oleaga et al., 2012) \\
\hline & SKBR3 cells & $\begin{array}{l}\text { Cocoa extract } \\
(250 \mathrm{ng} / \mu \mathrm{L})\end{array}$ & $24 \mathrm{~h}$ & $\uparrow$ CYP1A1 mRNA & (Oleaga et al., 2012) \\
\hline & MCF-7 cells & $\mathrm{EC}(25-100 \mu \mathrm{M})$ & $72 \mathrm{~h}$ & $\begin{array}{l}\downarrow \text { CYP1A1 activity, } \downarrow \text { NADPH cytochrome c } \\
\text { oxidase activity }\end{array}$ & (Rodgers \& Grant, 1998) \\
\hline \multirow[t]{12}{*}{ Liver } & Microsomes & $\begin{array}{l}\text { Cacao extract } \\
(1.325-13.25 \mathrm{mg} / \mathrm{mL}, \\
38.89 \mathrm{mg} \text { polyphenols/g } \\
\text { cacao powder) }\end{array}$ & $48 \mathrm{~h}$ & $\downarrow$ CYP1A1 activity & $\begin{array}{l}\text { (Ohno, Sakamoto, Ishizuka \& } \\
\text { Fujita, 2009) }\end{array}$ \\
\hline & HepG 2 cells & Catechin $(10-50 \mu \mathrm{M})$ & $24 \mathrm{~h}$ & $\downarrow$ CYP1A1 activity, $\uparrow$ UDP-GT & (Haza \& Morales, 2011) \\
\hline & & $\mathrm{EC}(10-50 \mu \mathrm{M})$ & $24 \mathrm{~h}$ & $\downarrow \mathrm{CYP} 1 \mathrm{~A} 1$ activity, $=\mathrm{UDP}-\mathrm{GT}$ & (Haza \& Morales, 2011) \\
\hline & HepG 2 cells & $\mathrm{CPE}(5 \mu \mathrm{g} / \mathrm{mL})$ & $20 \mathrm{~h}$ & $\uparrow \mathrm{GPx}, \uparrow \mathrm{GR}, \downarrow \mathrm{ROS}$ & (Martín et al., 2010a) \\
\hline & HepG 2 cells & $\mathrm{EC}(25-100 \mu \mathrm{M})$ & $24 \mathrm{~h}$ & $\downarrow$ ROS & (Granado-Serrano et al., 2007) \\
\hline & HepG2 cells & $\mathrm{EC}(10 \mu \mathrm{M})$ & 4 and $18 \mathrm{~h}$ & $\downarrow \mathrm{ROS}, \uparrow \mathrm{Nrf} 2, \uparrow \mathrm{NF}-\mathrm{\kappa B}, \uparrow \mathrm{AP}-1$ & (Granado-Serrano et al., 2010) \\
\hline & Wistar rats & Catechin $(2 \mathrm{~g} / \mathrm{kg}$ diet $)$ & $3 \mathrm{w}$ & $\begin{array}{l}=\mathrm{CAT},=\mathrm{GPx},=\mathrm{GST},=\mathrm{SOD},=\text { lipid } \\
\text { peroxidation, }=\mathrm{GSH}, \downarrow \mathrm{NQO} 1\end{array}$ & (Wiegand et al., 2009) \\
\hline & HepG2 cells & $\mathrm{CPE}(0.5-50 \mu \mathrm{g} / \mathrm{mL})$ & 2 and $20 \mathrm{~h}(\mathrm{~b})$ & $\begin{array}{l}t \text {-BOOH-treated cells: } \uparrow \text { GSH }, \downarrow \text { ROS }, \downarrow \\
\text { MDA }, \downarrow \text { GPx }, \downarrow \text { GR }\end{array}$ & (Martín et al., 2008) \\
\hline & HepG 2 cells & $\mathrm{EC}(10 \mu \mathrm{M})$ & 4 and $18 \mathrm{~h}(\mathrm{~b})$ & $t$-BOOH-treated cells: $\downarrow$ cell death & (Granado-Serrano et al., 2009a) \\
\hline & HepG2 cells & $\mathrm{EC}(50-100 \mu \mathrm{M})$ & 2 and $20 \mathrm{~h}(\mathrm{~b})$ & $\begin{array}{l}t \text {-BOOH-treated cells: } \downarrow \text { GPx }, \downarrow \text { GR }, \downarrow \text { ROS }, \uparrow \\
\text { GSH }, \downarrow \text { MDA }\end{array}$ & (Martín et al., 2010b) \\
\hline & HepG2 cells & $\mathrm{EC}(25 \mu \mathrm{M})$ & $12 \mathrm{~h} \mathrm{(b)}$ & $t$-BOOH-treated cells: $\downarrow$ GSSG,$\uparrow \mathrm{GSH}$ & (Murakami et al., 2002) \\
\hline & $\begin{array}{l}\text { Swiss albino } \\
\text { mice (also } \\
\text { kidney) }\end{array}$ & $\begin{array}{l}\text { Catechin }(40 \mathrm{mg} / \mathrm{kg} \\
\text { b.w.) }\end{array}$ & $10 \mathrm{~d}(\mathrm{~b}-\mathrm{d}-\mathrm{p})$ & $\begin{array}{l}\text { Tamoxifen-treated mice: } \downarrow \text { protein and lipid } \\
\text { oxidation, } \downarrow \text { superoxide, } \uparrow \text { SOD } \uparrow \text { GPx, } \uparrow \text { GR, } \\
\uparrow \text { GST, } \uparrow \text { CAT, } \uparrow \text { GSH }, \downarrow \text { GSSG }, \uparrow \text { CYP }\end{array}$ & $\begin{array}{l}\text { (Parvez et al., 2006; Tabassum et } \\
\text { al., 2007) }\end{array}$ \\
\hline
\end{tabular}




\begin{tabular}{|c|c|c|c|c|c|}
\hline & $\begin{array}{l}\text { Wistar rats } \\
\text { ICR mice } \\
\text { Swiss albino } \\
\text { mice } \\
\text { BALB/cN mice }\end{array}$ & $\begin{array}{l}\text { Cocoa }(16 \%, 755 \mathrm{mg} \\
\text { flavanols/100 g cocoa) } \\
\text { PB2 }(25-100 \mathrm{mg} / \mathrm{kg}, \\
\text { gavage }) \\
\text { EC }(15 \mathrm{mg} / \mathrm{kg} \text { b.w. }) \\
\text { Cocoa extract } \\
(34.5 \mathrm{mg} / \mathrm{kg}, \text { i.p., } 50.4 \\
\mathrm{mg} \text { flavanols/g dry } \\
\text { matter }) \\
\text { EC }(2.51 \mathrm{mg} / \mathrm{kg}, \text { i.p. })\end{array}$ & $\begin{array}{l}7 \mathrm{~d}(\mathrm{~b}-\mathrm{d}-\mathrm{p}) \\
3 \mathrm{~d}(\mathrm{~b}-\mathrm{d}-\mathrm{p}) \\
2 \mathrm{w}(\mathrm{p})\end{array}$ & $\begin{array}{l}\text { DEN-treated rats: } \uparrow \mathrm{GSH}, \uparrow \mathrm{GPx}, \uparrow \mathrm{GST}, \uparrow \\
\mathrm{CAT},=\mathrm{GR} \\
\mathrm{CCl}_{4} \text {-treated mice: } \downarrow \text { MDA, } \uparrow \mathrm{GPx}, \uparrow \mathrm{SOD}, \uparrow \\
\mathrm{CAT}, \downarrow \mathrm{COX}-2, \downarrow \text { iNOS }, \downarrow \text { NF-KB } \\
\text { 5-Cy }{ }^{60} \mathrm{Co} \gamma \text {-irradiation: } \downarrow \text { lipid peroxidation, } \downarrow \\
\mathrm{NF}-\mathrm{KB}, \uparrow \text { SOD, } \uparrow \mathrm{CAT}, \uparrow \mathrm{GSH} \\
\uparrow \mathrm{SOD}, \uparrow \mathrm{CAT}, \uparrow \text { total protein thiols }\end{array}$ & $\begin{array}{l}\text { (Yang, Zhang, Guan \& Hua, 2015) } \\
\text { (Sinha et al., 2012) } \\
\text { (Giacometti, Muhvic', Pavletic' \& } \\
\text { Đudaric, 2016) }\end{array}$ \\
\hline Colon & $\begin{array}{l}\text { Sprague-Dawley } \\
\text { rats } \\
\text { Caco-2 cells } \\
\text { Caco-2 cells }\end{array}$ & $\begin{array}{l}\text { Catechin } \\
(14 \text { and } 35 \mathrm{mg} / \mathrm{kg} / \text { day }) \\
\text { Hexameric procyanidin } \\
(2.5-20 \mu \mathrm{M}) \\
\mathrm{EC}(0.5-5 \mu \mathrm{M}) \\
\text { Hexameric procyanidin } \\
(2.5-20 \mu \mathrm{M}) \\
\text { Chocolate }(12 \%, 43 \mathrm{mg} \\
\text { procyanidin } / \mathrm{g}) \\
\text { Cocoa }(10 \%, 755 \mathrm{mg}\end{array}$ & $\begin{array}{l}20 \mathrm{~h} \\
20 \mathrm{~h} \mathrm{(b)} \\
4,8 \text { and } 20 \mathrm{~h} \\
(\mathrm{~b}) \\
20 \mathrm{~h} \mathrm{(b)} \\
5 \mathrm{~h} \\
5 \mathrm{~h} \mathrm{(b)} \\
21 \mathrm{~d}\end{array}$ & $\begin{array}{l}\uparrow \text { GPx, } \uparrow \text { GR, } \uparrow \text { GST } \\
t \text {-BOOH-treated cells: } \downarrow \text { ROS } \\
t \text {-BOOH-treated cells: } \uparrow \text { GSTP1, } \uparrow \text { Nrf2 } \\
\text { acrylamide-treated cells: } \uparrow \text { GSH, } \downarrow \text { ROS } \\
\text { CPE and PB2: } \uparrow \text { GCS, } \uparrow \text { GST } \\
\uparrow \text { Nrf2, } \uparrow \text { HO- } 1 \\
\text { Ketoprofen-treated cells: } \downarrow \text { MDA, } \downarrow \text { ROS }, \uparrow \\
\text { GPx, } \uparrow \text { GR, } \uparrow \text { TSH } \\
\text { Ketoprofen-treated rats: } \downarrow \text { MDA, } \downarrow 8 \text {-OHdG, } \\
\uparrow \text { GSH, } \uparrow \text { GSH/GSSG, } \uparrow \text { GPx, } \uparrow \text { GR } \\
\text { Deoxycholic-treated cells: } \downarrow \text { ROS, } \downarrow \text { NADPH } \\
\text { oxidase, } \downarrow \text { AP- } 1, \downarrow \text { Ca } 2+ \\
\text { TNF } \alpha \text {-treated cells: } \downarrow \text { ROS, } \downarrow \text { NADPH } \\
\text { oxidase, } \downarrow \text { iNOS, } \downarrow \text { NF-KB } \\
\text { AOM-treated rats: } \downarrow \text { COX- } 2, \downarrow \text { NF-KB, } \uparrow \text { CAT } \\
\text { AOM-treated rats: } \downarrow \text { MDA }, \downarrow \text { protein }\end{array}$ & $\begin{array}{l}\text { (Rodriguez-Ramiro et al., 2011a) } \\
\text { (Rodriguez-Ramiro et al., 2011a) } \\
\text { (Rodriguez-Ramiro et al., 2012) } \\
\text { (Rodriguez-Ramiro et al., 2011b) } \\
\text { (Rodriguez-Ramiro et al., 2011b) } \\
\text { (Cheng, Wu, Ho \& Yen, 2013) } \\
\text { (Cheng et al., 2013) } \\
\text { (Cheng et al., 2013) } \\
\text { (Da Silva et al., 2012; Erlejman, } \\
\text { Fraga \& Oteiza, 2006) } \\
\text { (Contreras, Ricciardi, Cremonini \& } \\
\text { Oteiza, 2015; Erlejman, Jaggers, } \\
\text { Fraga \& Oteiza, 2008) } \\
\text { (Hong et al., 2013) } \\
\text { (Rodriguez-Ramiro et al., 2013; }\end{array}$ \\
\hline
\end{tabular}




\begin{tabular}{|c|c|c|c|c|c|}
\hline & $\mathrm{BALB} / \mathrm{c}$ mice & $\begin{array}{l}\text { flavanols/100 g cocoa) } \\
\text { Cocoa (5 and } 10 \%)\end{array}$ & $8 \mathrm{w}(\mathrm{b}-\mathrm{d}-\mathrm{p})$ & $\begin{array}{l}\text { oxidation, } \uparrow \mathrm{GPx}, \uparrow \mathrm{GR}, \uparrow \mathrm{GST}, \uparrow \mathrm{GSH}, \downarrow \\
\mathrm{COX}-2, \downarrow \text { iNOS, } \downarrow \text { NF-kB } \\
\text { AOM/DSS-treated mice: } \downarrow \text { MDA, } \downarrow \text { COX- } 2, \downarrow \\
\text { iNOS, } \uparrow \text { SOD }, \uparrow \mathrm{CAT}, \uparrow \mathrm{GPx}, \uparrow \mathrm{GR}, \uparrow \mathrm{GSH}, \\
\uparrow \mathrm{Nrf}, \uparrow \text { NQO1, } \uparrow \text { UDP-GT }\end{array}$ & $\begin{array}{l}\text { Rodriguez-Ramiro et al., 2011c) } \\
\text { (Pandurangan et al., 2015) }\end{array}$ \\
\hline Brain & $\begin{array}{l}\text { Astrocytes } \\
\text { Astrocytes } \\
\text { SH-SY5Y cells }\end{array}$ & $\begin{array}{l}\text { EC }(100 \mathrm{nM}) \\
\text { Catechin }(0.1-10 \mu \mathrm{M}) \\
\text { Cocoa extract } \\
(5-30 \mu \mathrm{g} / \mathrm{mL}) \\
\mathrm{EC}(12.4-100 \mu \mathrm{M})\end{array}$ & $\begin{array}{l}6 \mathrm{~h} \\
2 \text { or } 7 \mathrm{~d} \\
30 \min (b)\end{array}$ & $\begin{array}{l}\uparrow \mathrm{GSH}, \uparrow \mathrm{Nrf} 2 \\
\uparrow \mathrm{SOD}, \uparrow \mathrm{CAT}, \uparrow \mathrm{GPx} \\
\mathrm{H}_{2} \mathrm{O}_{2} / \mathrm{Fe}^{2+} \text {-treated cells: } \downarrow \text { ROS }\end{array}$ & $\begin{array}{l}\text { (Bahia, Rattray \& Williams, 2008) } \\
\text { (Chan et al., 2002) } \\
\text { (Ramiro-Puig et al., 2009) }\end{array}$ \\
\hline Skin & $\begin{array}{l}\text { BALB/c mice } \\
\text { BALB/c mice }\end{array}$ & $\begin{array}{l}\text { Catechin }(2 \%) \\
\text { Catechin }\left(1 \mathrm{mg} / \mathrm{cm}^{2}\right. \\
\text { topical })\end{array}$ & $\begin{array}{l}2 \text { or } 4 \mathrm{w}(\mathrm{b}-\mathrm{d}- \\
\text { p) }\end{array}$ & $\begin{array}{l}\text { UVB-irradiated mice: } \uparrow \mathrm{CAT}, \uparrow \mathrm{SOD}, \uparrow \\
\text { (transiently) GPx } \\
\text { DMBA/TPA: } \downarrow \text { MDA, } \uparrow \mathrm{SOD}, \uparrow \mathrm{CAT}, \uparrow \\
\mathrm{GST}, \uparrow \mathrm{GPx}, \uparrow \mathrm{GR}, \uparrow \mathrm{GSH}, \downarrow \mathrm{COX}-2, \downarrow \\
\mathrm{iNOS}, \downarrow \text { NF-KB }\end{array}$ & $\begin{array}{l}\text { (Jeon et al., 2003) } \\
\text { (Monga et al., 2014) }\end{array}$ \\
\hline $\begin{array}{l}\text { Endometri } \\
\mathrm{o}\end{array}$ & RL95 cells & Catechin $(150 \mu \mathrm{M})$ & 24 h (b-d-p) & $\mathrm{H}_{2} \mathrm{O}_{2}$-treated cells: $\downarrow$ cell viability & (Estany et al., 2007) \\
\hline
\end{tabular}

${ }^{a}$ h, hours; w, weeks; d, days; before (b), during (d), post (p) stress/carcinogen treatment.

${ }^{\mathrm{b}}$ The arrow indicate an increase $(\uparrow)$ or decrease $(\downarrow)$ in the levels or activity of the different parameters analysed, and $(=)$ designates unmodified parameters. 
Table 3. Effects of cocoa and cocoa flavanols on antioxidant and pro-oxidant enzymes and biomarkers of oxidative stress in the cardiovascular system.

\begin{tabular}{|c|c|c|c|c|}
\hline $\begin{array}{l}\text { Experimental } \\
\text { model }\end{array}$ & Treatment (dose) & Duration $^{\mathrm{a}}$ & Main effects ${ }^{b}$ & Reference \\
\hline $\begin{array}{l}\text { Aortic rings } \\
\text { L-NAME rats } \\
\text { Aortic rings } \\
\text { DOCA-salt rats } \\
\text { HUVEC } \\
\text { endothelial cells } \\
\text { HUVEC } \\
\text { endothelial cells } \\
\text { Aortic rings } \\
\text { L-NAME rats } \\
\text { Aortic rings } \\
\text { High-fructose-fed } \\
\text { rats } \\
\text { Heart } \\
\text { L-NAME rats } \\
\text { Human smokers } \\
\text { Peripheral artery } \\
\text { disease patients } \\
\text { Middle-aged } \\
\text { volunteers }\end{array}$ & $\begin{array}{l}\text { EC ( } 20 \mathrm{mg} / \mathrm{kg} \text { b.w, daily) } \\
\text { EC ( } 4 \mathrm{~g} \text { of EC/kg diet) } \\
40 \mathrm{~g} \text { of dark chocolate } \\
\text { ( } 799 \mathrm{mg} / \mathrm{L} \text { total } \\
\text { polyphenols) } \\
40 \mathrm{~g} \text { of dark chocolate } \\
\text { ( } 799 \mathrm{mg} / \mathrm{L} \text { total } \\
\text { polyphenols) } \\
1.4 \mathrm{~g} \text { of cocoa extract } \\
\text { (645.3 mg polyphenols) }\end{array}$ & $\begin{array}{l}1 \mathrm{~h}(\mathrm{~b}, \mathrm{~d}) \\
6 \mathrm{~h} \\
4 \mathrm{~d} \\
8 \mathrm{w}\end{array}$ & $\begin{array}{l}\downarrow \text { plasma MDA, } \downarrow \text { urinary } 8 \text {-isoprostaglandin, } \downarrow \text { superoxide, } \downarrow \\
\text { NADPH oxidase, } \downarrow \text { p22phox } \\
\downarrow \text { plasma MDA, } \downarrow \text { urinary } 8 \text {-isoprostaglandin, } \downarrow \text { superoxide }, \uparrow \\
\text { Nrf } \uparrow \uparrow \text { NQO } 1, \uparrow \text { GCLC, } \uparrow \text { HO- } 1, \downarrow \text { NADPH oxidase, } \downarrow \text { p22phox, } \\
\downarrow \text { p47phox } \\
\downarrow \text { superoxide },=\text { HO- } 1 \\
\downarrow \text { superoxide, } \downarrow \text { NADPH oxidase } \\
\downarrow \text { plasma MDA, } \downarrow \text { GSH, } \downarrow \text { superoxide, } \downarrow \text { p47phox } \\
\downarrow \text { superoxide }, \downarrow \text { p22phox, } \downarrow \text { p47phox } \\
\downarrow \text { GSH, } \downarrow \text { superoxide }, \downarrow \text { NADPH oxidase }, \downarrow \text { p47phox } \\
\downarrow \text { urinary isoprostanes, } \downarrow \text { NADPH oxidase } \\
\downarrow \text { urinary isoprostanes, } \downarrow \text { NADPH oxidase } \\
\downarrow \text { oxLDL }, \downarrow \text { MPO }\end{array}$ & $\begin{array}{l}\text { (Gómez-Guzmán et al., } \\
\text { 2011) } \\
\text { (Gomez-Guzman et al., } \\
\text { 2012) } \\
\text { (Ruijters et al., 2013) } \\
\text { (Steffen, Gruber, Schewe \& } \\
\text { Sies, 2008) } \\
\text { (Litterio et al., 2012) } \\
\text { (Litterio et al., 2015) } \\
\text { (Piotrkowski, Calabró, } \\
\text { Galleano \& Fraga, 2015) } \\
\text { (Loffredo et al., 2011) } \\
\text { (Loffredo et al., 2014) } \\
\text { (Ibero-Baraibar et al., 2014) }\end{array}$ \\
\hline
\end{tabular}


${ }^{a} \mathrm{~h}$, hours; w, weeks; d, days; before (b), during (d) stress treatment.

${ }^{\mathrm{b}}$ The arrow indicate an increase $(\uparrow)$ or decrease $(\downarrow)$ in the levels or activity of the different parameters analysed, and $(=)$ designates unmodified parameters. 
Table 4. Effects of cocoa and cocoa flavanols in biomarkers of oxidative stress in central tissues and organs involved in diabetes

\begin{tabular}{|c|c|c|c|c|c|}
\hline Tissue & $\begin{array}{l}\text { Experimental } \\
\text { model }\end{array}$ & Treatment (dose) & Duration $^{\mathrm{a}}$ & Main effects & Reference \\
\hline \multirow{8}{*}{$\begin{array}{l}\text { Pancrea } \\
\text { s }\end{array}$} & \multirow[t]{2}{*}{ INS-1E beta cells } & \multirow[t]{2}{*}{ CPE $(5-20 \mu \mathrm{g} / \mathrm{mL})$} & $20 \mathrm{~h}$ & $\uparrow \mathrm{GPx}, \uparrow \mathrm{GR},=\mathrm{GSH}$ & (Martin et al., 2013) \\
\hline & & & $20 \mathrm{~h}(\mathrm{~b})$ & $t$-BOOH-treated cells: $\downarrow$ ROS, $\downarrow$ carbonyl groups & (Martin et al., 2013) \\
\hline & \multirow[t]{2}{*}{ INS-1E beta cells } & \multirow[t]{2}{*}{$\mathrm{EC}(5-20 \mu \mathrm{M})$} & $20 \mathrm{~h}$ & $\uparrow \mathrm{GPx}, \uparrow \mathrm{GR},=\mathrm{GSH}$ & (Martin et al., 2014) \\
\hline & & & $20 \mathrm{~h}(\mathrm{~b})$ & $t$-BOOH-treated cells: $\downarrow$ ROS,$\downarrow$ carbonyl groups & (Martin et al., 2014) \\
\hline & HIT beta cells & Catechin $(50 \mu \mathrm{M})$ & $24 \mathrm{~h}(\mathrm{~b})$ & $\mathrm{H}_{2} \mathrm{O}_{2}$-treated cells: $\downarrow$ TBARS & (Lapidot, Walker \& Kanner, \\
\hline & INS-1E beta cells & DHPAA $(5 \mu \mathrm{M})$, HPPA $(1$ & $20 \mathrm{~h}(\mathrm{~b})$ & $t$-BOOH-treated cells: $\downarrow$ ROS,$\downarrow$ carbonyl groups & 2002) \\
\hline & ZDF diabetic rats & $\mu \mathrm{M})$ & $9 \mathrm{w}$ & $=\mathrm{GSH}, \uparrow \mathrm{GPx}, \uparrow \mathrm{GR}, \downarrow$ carbonyl groups, $\downarrow$ & (Fernández-Millán et al., 2014) \\
\hline & & $\begin{array}{l}\text { Cocoa-rich diet }(10 \%, 755 \\
\text { mg flavanols/100 g cocoa })\end{array}$ & & TBARS & (Fernández-Millán et al., 2015) \\
\hline \multirow[t]{4}{*}{ Liver } & HepG2 cells & $\mathrm{CPE}(1 \mu \mathrm{g} / \mathrm{mL}), \mathrm{EC}(10 \mu \mathrm{M})$ & $24 \mathrm{~h}(\mathrm{~b})$ & $\begin{array}{l}\text { High-glucose-treated cells: } \uparrow \mathrm{GSH}, \uparrow \mathrm{GPx}, \uparrow \mathrm{GR}, \\
\downarrow \text { ROS }, \downarrow \text { carbonyl groups }\end{array}$ & $\begin{array}{l}\text { (Cordero-Herrera, Martin, Goya } \\
\text { \& Ramos, 2015a) }\end{array}$ \\
\hline & ZDF diabetic rats & $\begin{array}{l}\text { Cocoa-rich diet }(10 \%, 755 \\
\text { mg flavanols/100 g cocoa) }\end{array}$ & $9 w$ & $\begin{array}{l}=\mathrm{GSH},=\mathrm{GPx},=\mathrm{GR}, \downarrow \mathrm{Nrf} 2, \downarrow \mathrm{ROS}, \downarrow \text { carbonyl } \\
\text { groups, } \uparrow \mathrm{SOD}, \downarrow \mathrm{HO}-1\end{array}$ & $\begin{array}{l}\text { (Cordero-Herrera, Martin, Goya } \\
\text { \& Ramos, 2015b) }\end{array}$ \\
\hline & $\begin{array}{l}\text { Diabetic }(\mathrm{db} / \mathrm{db}) \\
\text { mice }\end{array}$ & EC (150 mg/kg body weight) & $15 \mathrm{w}$ & $\uparrow \mathrm{GSH}, \uparrow \mathrm{SOD}$ & (Si et al., 2011) \\
\hline & High fructose rats & EC (20 mg /Kg body weight) & $8 \mathrm{w}$ & $\downarrow$ carbonyl groups, $\downarrow$ NOX & (Bettaieb et al., 2014) \\
\hline Adipose & High fructose rats & EC (20 mg /Kg body weight) & $8 \mathrm{w}$ & $\downarrow$ carbonyl groups, $\downarrow$ NOX & (Bettaieb et al., 2014) \\
\hline \multirow[t]{2}{*}{ Muscle } & \multirow{2}{*}{$\begin{array}{l}\text { High fat diet mice } \\
\text { T2D patients }\end{array}$} & EC (1 mg /kg body weight) & $15 \mathrm{~d}$ & $\uparrow \mathrm{GSH}, \uparrow \mathrm{SOD} 2, \uparrow \mathrm{CAT}, \downarrow$ protein carbonylation & (Ramirez-Sanchez et al., 2013) \\
\hline & & $\begin{array}{l}\text { Dark chocolate or cocoa } \\
\text { beverages (100 } \mathrm{mg} \text { EC/day) }\end{array}$ & $3 \mathrm{~m}$ & $\begin{array}{l}\uparrow \mathrm{GSH}, \uparrow \mathrm{SOD} 2, \uparrow \mathrm{CAT}, \downarrow \text { protein } \\
\text { carbonylation, } \uparrow \text { FOXO1, } \uparrow \text { PGC } 1 \alpha\end{array}$ & (Ramirez-Sanchez et al., 2013) \\
\hline
\end{tabular}

\footnotetext{
${ }^{a}$ h, hours; w, weeks; d, days; m, months; before (b) stress treatment.

${ }^{\mathrm{b}}$ The arrow indicates an increase $(\uparrow)$ or decrease $(\downarrow)$ in the levels or activity of the different parameters analysed, and $(=)$ designates unmodified parameters.
} 
Figure 1<smiles>Cc1c(O)cc(O)cc1O[C@@H](c1ccc(O)c(O)c1)[C@H](C)O</smiles>

(-) Epicatechin<smiles>Oc1cc(O)c2c(c1)O[C@H](c1ccc(O)c(O)c1)[C@H](O)[C@H]2c1c(O)cc(O)c2c1O[C@H](c1ccc(O)c(O)c1)[C@H](O)C2</smiles>

Procyanidin B2<smiles>Oc1cc(O)c2c(c1)O[C@H](c1ccc(O)c(O)c1)[C@H](O)C2</smiles>

(-) Catechin<smiles>Oc1cc(O)c2c(c1)O[C@H](c1ccc(O)c(O)c1)[C@H](O)[C@H]2c1c(O)cc(O)c2c1O[C@H](c1ccc(O)c(O)c1)[C@H](O)C2</smiles>

Procyanidin B1 
Figure 2

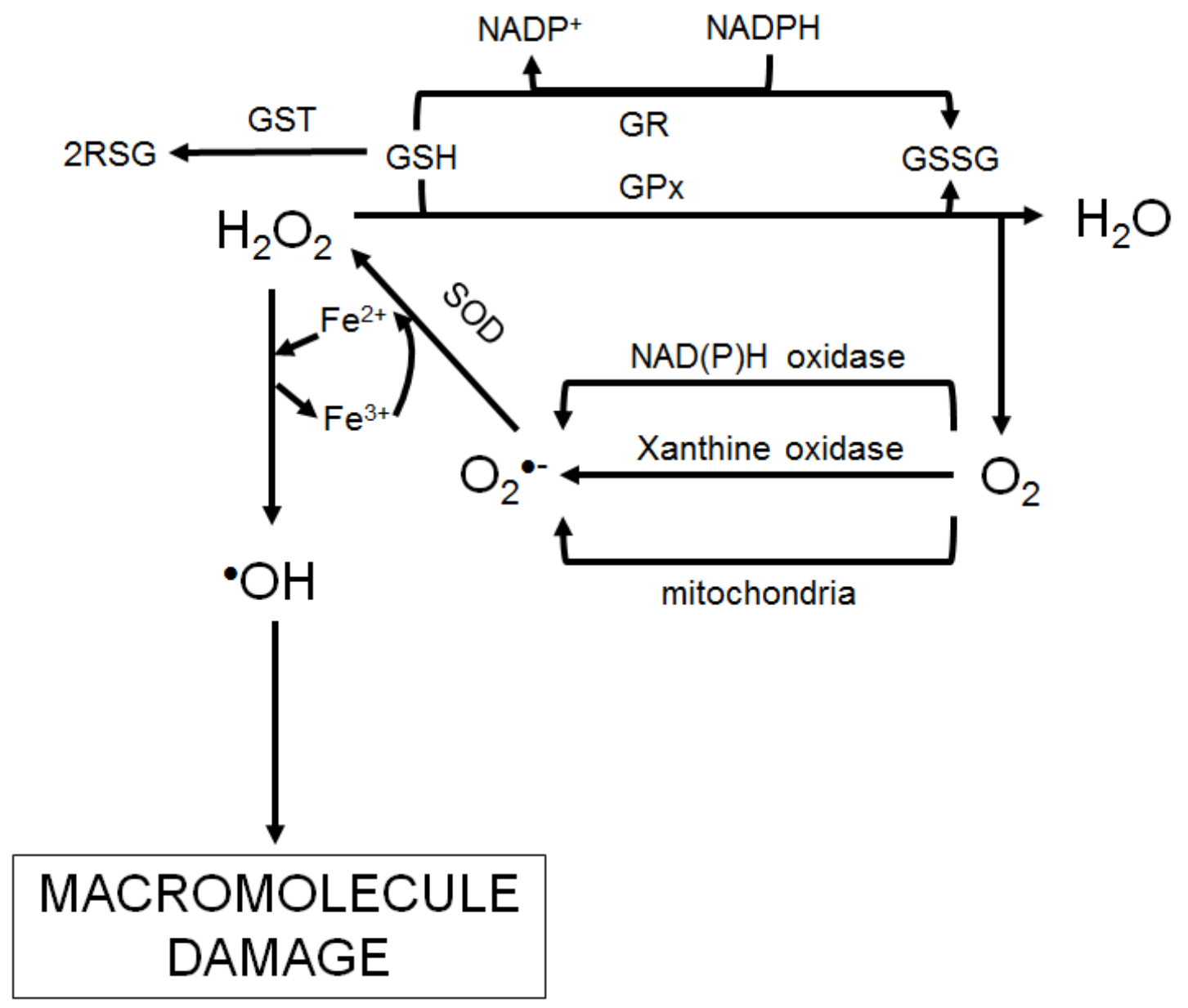

